\title{
New fossil stilt-legged mites of Neophyllobius Berlese, 1886 (Acariformes, Camerobiidae) from Eocene Baltic amber
}

\author{
Mateusz Zmudzinski $\odot$
}

Department of Animal Morphology, Faculty of Biology, Adam Mickiewicz University, Poznań, Uniwersytetu Poznańskiego 6, 61-614

Poznań, Poland <mat.zmudzinski@gmail.com>

\begin{abstract}
The fossil record of the family Camerobiidae has been represented by only one species, Neophyllobius succineus Bolland and Magowski, 1990, described from Eocene Baltic amber. These prostigmatan mites are distinguishable by their distinctly long and slender stilt-like legs, and they are associated with aboveground vegetation where they hunt for other small invertebrates. This paper enhances the knowledge of fossil stilt-legged mites. Two new fossil species, $N$. electrus new species and $N$. glaesus new species, are described from samples of Baltic amber, and remarks on their morphology and taphonomy are provided. The discovery is complemented with a discussion on morphological singularities (the shape of the prodorsum, the location of setae $h 1$ and $h 2$ in living specimens, and lengths of genual setae), an anomaly of hypertrophied seta (found in the $N$. glaesus holotype), and some biogeographical issues.
\end{abstract}

UUID: http://zoobank.org/d1602384-ae4f-4f90-b4a1-6cdedd77c9e1

\section{Introduction}

Mites of the family Camerobiidae (Acariformes, Prostigmata, Raphignathoidea) are recognizable by an almost round (especially when it comes to specimens mounted on microscope slides), dorsoventrally flattened idiosoma that is suspended on long, slender, stilt-like legs, mostly with long setae, which yield a characteristic appearance (Bolland, 1986, 1991). Camerobiids are free-living predators of small invertebrates (e.g., plant-associated mites and crawlers of scale insects [Hemiptera, Coccoidea]). Camerobiids hunt their prey on aboveground vegetation (including tree bark) but have also been found in the litter (Gerson et al., 2003; Walter et al., 2009). In the literature, more than 160 extant species have been described in seven genera: Acamerobia Fan and Walter, 2011; Bisetulobius du Toit, Theron, and Ueckermann, 1998; Camerobia Southcott, 1957; Decaphyllobius Bolland, 1986; Neophyllobius Berlese, 1886; Tillandsobius Bolland, 1986; and Tycherobius Bolland, 1986. Most species are monotypic, and the reason for this is the single, rare occurrence of these mites, which probably do not occur in larger aggregations as adults (Bolland, 1986, 2001). The historical aspect of the developing systematics hypotheses of the family and its constituent genera was summarized by Fan and Walter (2011).

Baltic amber is one of the richest sources of animal remains, which are exceptionally well preserved in the form of threedimensional inclusions. Despite the long history of research on fossil organisms (Koch and Berendt, 1854 published the first study that included mites), new information is continually provided on the structure of the so-called Eocene Amber Forests (Weitschat and Wichard, 2002; Seyfullah et al., 2018). In addition, because of a diverse paleoacarofauna including the presence of minute and weakly sclerotized mites, this Lagerstätte is essential for further paleoacarological studies (Sidorchuk, 2018).

The fossil record of the superfamily Raphignathoidea is scarce and consists of only two described species: Mediolata eocenia Kuznetsov, Khaustov, and Perkovsky, 2010 (Stigmaeidae) from Rovno amber and Neophyllobius succineus Bolland and Magowski, 1990 from Baltic amber (Dunlop et al., 2019). None of the studied inclusions was subjected to appropriate grinding techniques (which were developed later) helpful for studying microarthropods (Sidorchuk, 2013; Sidorchuk and Vorontsov, 2018), and quality pictures of the specimens were not taken (there is only one black-and-white photograph in Kuznetsov et al., 2010).

This work presents descriptions of two new fossil species, Neophyllobius electrus n. sp. and N. glaesus n. sp., which were found in samples of Baltic amber (Fig. 1). These decriptions are accompanied by detailed images, line drawing interpretations, and reconstructions of their habitus. Thus, the paper expands the knowledge about the Camerobiidae mites inhabiting the extinct Eocene ecosystem where resin originated.

\section{Materials and methods}

Materials.-1. Baltic amber sample with two inclusions determined by Ekaterina Sidorchuk as postlarval Camerobiidae and adult Phthiracaroidea from the Senckenberg Museum of Natural History Görlitz, Am Museum 1, 02826 Görlitz, Germany, under the collection (Sammlung Oribatida) number SMNG 07/36290-78.

2. Baltic amber with a representative of Camerobiidae from the private collection of the author and subsequently donated and deposited in the Geological-Paleontological 


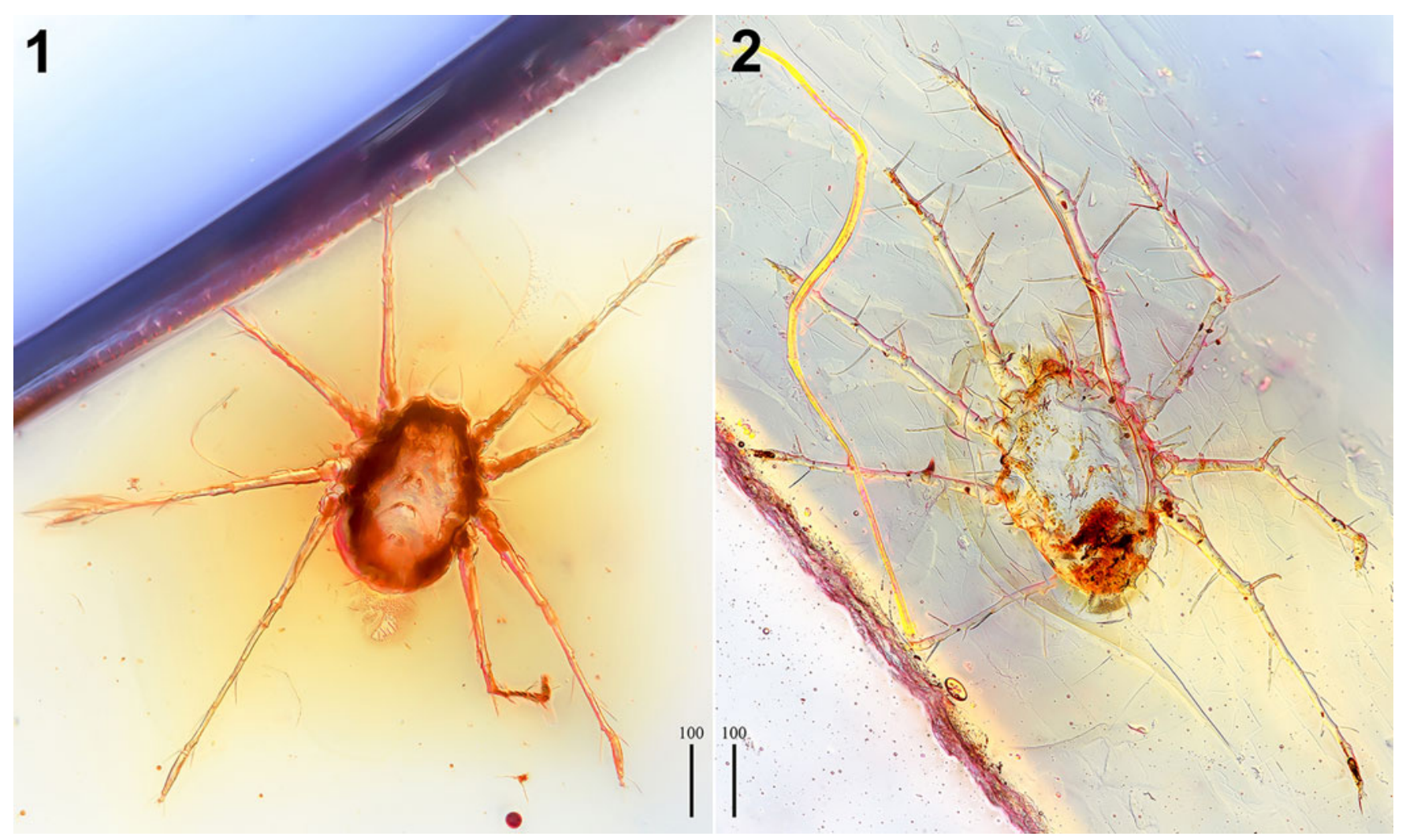

Figure 1. Habitus of studied inclusions: (1) Neophyllobius glaesus n. sp. (SMNG 07/36290-78a); (2) Neophyllobius electrus n. sp. (GPIH 4995a). Scale bars $=100 \mu \mathrm{m}$.

Institute and Museum of the University of Hamburg, now CeNakCentrum für Naturkunde, 'Geomatikum,' Bundesstraße 55, 20146 Hamburg, Germany, under the collection number GPIH 4995; this institution is its final deposition after preparation and study.

Amber preparation.-Amber samples were cut using a handheld cutting tool (Proxxon Micromot 60/E), and then obtained pieces were polished according to methods of preparation described by Sidorchuk (2013), using the tools introduced by Sidorchuk and Vorontsov (2016, 2018). Because of cracks along a natural amber fissure and the small size of the preparation, some fragments were embedded in Buehler EpoThin 2 epoxy resin between two round glass coverslips. One sample that had not been embedded in the resin was placed in a test tube filled with aqueous thymol solution. All preparations are labeled following the information given in this paper.

Observations and imaging.-Observations were done with a light compound microscope Nikon Eclipse Ni-U equipped with differential interference contrast (DIC) optics, 10× plan apochromatic dry, and $40 \times$ and $60 \times$ apochromatic waterimmersion lens objectives. Image stacks were obtained with a Nikon DS-Ri2 microscope camera using Nikon NIS-Elements D imaging software (Nikon Corporation). All images were corrected for light, tone, noise, and sharpness using Adobe Photoshop Lightroom (Adobe Systems). Layered images were obtained by processing the focal planes with Helicon Focus
Pro (Helicon Soft Ltd) rendering method A; minor retouch of the final image has been conducted to make some morphological structures visible. Drawings are interpretations of studied inclusions and were made with Adobe Photoshop (Adobe Systems) with the aid of a graphic tablet Wacom Intuos Pro on the basis of obtained pictures. Reconstructions of the species' habitus are based on the studied material, data from the literature, and pictures of living specimens. Original images are available through Figshare data-set collections (see details provided in the Material sections of individual descriptions of species).

Measurements._All measurements are made and given herein in micrometers $(\mu \mathrm{m})$, and they are rounded to the nearest integer. Measurements have been made with the aid of Nikon NIS-Elements D (Nikon Corporation) calibrated for used objectives. Due to the nature of preservation, measurements of organs and body parts that are oriented in three-dimensional space should be considered as minimum estimates.

Repositories and institutional abbreviations. - Type specimens examined in this study are deposited in the following institutions: Senckenberg Museum of Natural History Görlitz (SMNG), Görlitz, Germany, and GeologicalPaleontological Institute and Museum of the University of Hamburg (GPIH), now CeNak-Centrum für Naturkunde, Hamburg, Germany. 


\section{Systematic paleontology}

Class Arachnida Cuvier, 1812

Superorder Acariformes Zakhvatkin, 1952

Order Trombidiformes Reuter, 1909

Suborder Prostigmata Kramer, 1877

Supercohort Eleutherengonides Oudemans, 1909

Cohort Raphignathina Kethley, 1982

Superfamily Raphignathoidea Kramer, 1877

Family Camerobiidae Southcott, 1957

Genus Neophyllobius Berlese, 1886

Type species.-Neophyllobius elegans Berlese, 1886 by original designation from material collected in Italy.

Terminology.-Terminology used here follows that developed in works by F. Grandjean (reviewed by Travé and Vachon, 1975; general terminology combined by van der Hammen, 1980). Its application to Camerobiidae follows Kethley (1990) and Fan and Walter (2011). The left and right sides of the body and its structures correspond to those of the dorsal view. Symbols and abbreviations used in the text are explained in the legends of the corresponding figures. Leg setae were designated with diligence on the basis of three-dimensional specimens. However, the nature of the appendages (long, slender, stilt-like) may cause difficulty in the correct determination of lateral and ventral setae; hence, the chaetotaxy of setae $l$ and $v$ on tibiae should be considered a simplification. Application of Grandjean's system for leg phanerotaxy has been already applied in the recent literature (e.g., Fan and Walter, 2011; Paredes-Leon et al., 2016; Khaustov and Abramov, 2017).

\section{Neophyllobius electrus new species} Figures 1.2, 2-6; Table 1

Holotype.-Adult female (Fig. 1.2) in two preparations that consist of polished amber embedded in epoxy resin between two round glass coverslips. One preparation (SMNG 07/ 36290-78a) contains most of the specimen's body. Another (SMNG 07/36290-78b) contains some parts of the ventral cuticle (Fig. 5.1) and partial tarsi I and II (Fig. 3.3, 3.8, 3.11). Type material is deposited in SMNG, Sammlung Oribatida, under the collection number 07/36290-78. Data from the label: Baltischer Bernstein, coll. Wunderlich, Ankauf 2007. Camerobiidae (postlarv) Phthiracaroidea (ad) det. Sidorchuk. See Zmudzinski (2020a) for original series of pictures of the specimen.

Diagnosis.-Peritremes with at least one loop. Fourteen pairs of barbed idiosomal setae present. Setae $v i$ and ve on anterior margin of prodorsum directed forward; together with $c 2, d 1, e 1$, and $f 1$ longer than other idiosomal setae; ratio $c 1$ : $c 2: d l=1: 2: 2.8$. Setae $d$ on genua I-IV barbed and relatively short (I, 51-60 $\mu \mathrm{m}$; II, $77 \mu \mathrm{m}$; III, 25-42 $\mu \mathrm{m}$; IV, $47 \mu \mathrm{m}$ ). Each of tarsi I-IV with only one midventral seta $v s$. Leg phanerotaxy formulae (trochanter to tarsus, tarsal setae estimated, $\kappa$ setae not

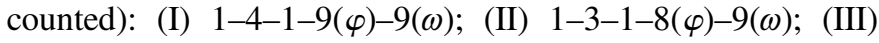

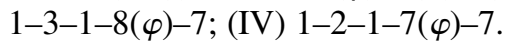

Occurrence.-Single inclusion within the sample of Baltic amber, middle Eocene 48-38 Ma (Weitschat and Wichard, 2002).

Description of inclusion.-Gnathosoma (Fig. 5.2) situated ventroterminally on the idiosoma, partially covered from above by the anterior part of the idiosomal prodorsum, $61 \mu \mathrm{m}$ long (measured from its base to the tip of the infracapitulum) and $62 \mu \mathrm{m}$ wide basally, cuticle striated only on palps. Stylophore stumpy, partially visible from dorsal view. Peritremes present but hardly visible. Cheliceral stylets retracted, visible inside the stylophore, each $17 \mu \mathrm{m}$ long. Subcapitulum smooth, without any ornamentation, with simple subcapitular setae: medial $m(10-13 \mu \mathrm{m}$ long; distance $m-m 9 \mu \mathrm{m})$ situated on its middle third, and short oral orl $(5-6 \mu \mathrm{m})$ and or $2(4 \mu \mathrm{m}$; visible only on the left side), almost on the tip of the infracapitulum. Palps directed anteriad, their total length 52-63 $\mu \mathrm{m}$. Palptrochanters without any setae. Palpfemora, each with lateral setae $l^{\prime \prime} 8-10 \mu \mathrm{m}$ long and dorsal setae $d 25-29 \mu \mathrm{m}$. Palpgenua with dorsal setae $d$ 14-17 $\mu \mathrm{m}$. Each palptibia with a longitudinal sclerotized structure (most likely a complex of palptibial setae and claw + palptarsus).

Idiosoma (Fig. 2) oval, $310 \mu \mathrm{m}$ long and $183 \mu \mathrm{m}$ wide (measured at the level of the bases of setae $c 2$ ). Cuticle partially striated, except prodorsum, midlateral dorsum, around the setae $d 1, e l$, and $f l$, and epimeral (coxal) fields. Dorsal idiosoma with fourteen pairs of barbed, relatively thick setae set on cuticular tubercles. Each tubercle single (not coupled). Setae vi (63-73 $\mu \mathrm{m}$ long; distance $v i-v i 26 \mu \mathrm{m})$ and $v e(53-56 \mu \mathrm{m}$; ve-ve $69 \mu \mathrm{m})$ directed forward and set on the largest protuberances situated on the anterior margin of prodorsum. Setae sci $(22-38 \mu \mathrm{m}$; sci-sci $112 \mu \mathrm{m})$ and sce $(26-27 \mu \mathrm{m} ;$ sce-sce $170 \mu \mathrm{m})$ on the lateral margins of prodorsum. Between them, just above the level of sce on each side, two eyes present, anterior one $(8.5 \mu \mathrm{m}$ in diameter) a little smaller than the posterior one $(10.5 \mu \mathrm{m})$. Four pairs of setae in the central part: $c 1$ the smallest $(24 \mu \mathrm{m}$ long; distance $c l-c l 12 \mu \mathrm{m}$ ) with distinctly marked barbs and $d l(66 \mu \mathrm{m} ; d l-d l 19 \mu \mathrm{m}), e l(68 \mu \mathrm{m} ;$ el-el $16 \mu \mathrm{m})$, and $f l$ (51-64 $\mu \mathrm{m} ; f 1-f 118 \mu \mathrm{m})$ much longer, gently bent backward, and similar in length. Setae $c 2(50 \mu \mathrm{m} ; c 2-c 2192 \mu \mathrm{m}), d 2$ (35-36 $\mu \mathrm{m} ; d 2-d 2159 \mu \mathrm{m}), e 2(44-45 \mu \mathrm{m} ; e 2-e 2141 \mu \mathrm{m})$, and $f 2(34-35 \mu \mathrm{m} ; f 2-f 2100 \mu \mathrm{m})$ situated on the lateral margins. Setae $h l(39-40 \mu \mathrm{m}, h 1-h 117 \mu \mathrm{m})$, and $h 2(28-31 \mu \mathrm{m} ; h 2-h 2$ $66 \mu \mathrm{m})$ terminate the idiosoma. Extremities of epimera visible from the dorsal side; the dorsolateral cuticle passes between second and third epimera. Supplementary distances: vi-ve 22$25 \mu \mathrm{m} ; v e-s c i \quad 50-52 \mu \mathrm{m}$; sci-sce $55 \mu \mathrm{m} ; c 1-c 2 \quad 92-95 \mu \mathrm{m}$;

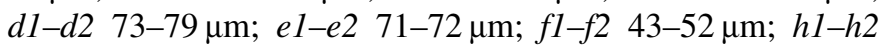
$18-25 \mu \mathrm{m} ; c 1-d 1$ 55-62 $\mu \mathrm{m} ; d 1-e 1$ 46-50 $\mu \mathrm{m} ;$ el-fl $66 \mu \mathrm{m}$; $f 2-h 232 \mu \mathrm{m} ; e 2-f 259 \mu \mathrm{m} ; d 2-e 253 \mu \mathrm{m} ; c 2-d 258 \mu \mathrm{m}$; sce$c 2$ 32-34 $\mu \mathrm{m}$. Coxal fields grouped into two areas: I partially fused with II, and coxal field III partially fused with IV. Epimeral setae slightly barbed and set on cuticular protuberances: $1 b$

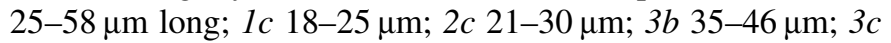
26-33 $\mu \mathrm{m} ; 4 b \quad 11-17 \mu \mathrm{m} ; 4 c 20-22 \mu \mathrm{m}$. The anogenital area (Fig. 5.3) visible, but difficult to discern its details. A pair of short, simple, smooth aggenital setae ag situated just above its anterior margin. Genital valves with one pair of short, simple, 


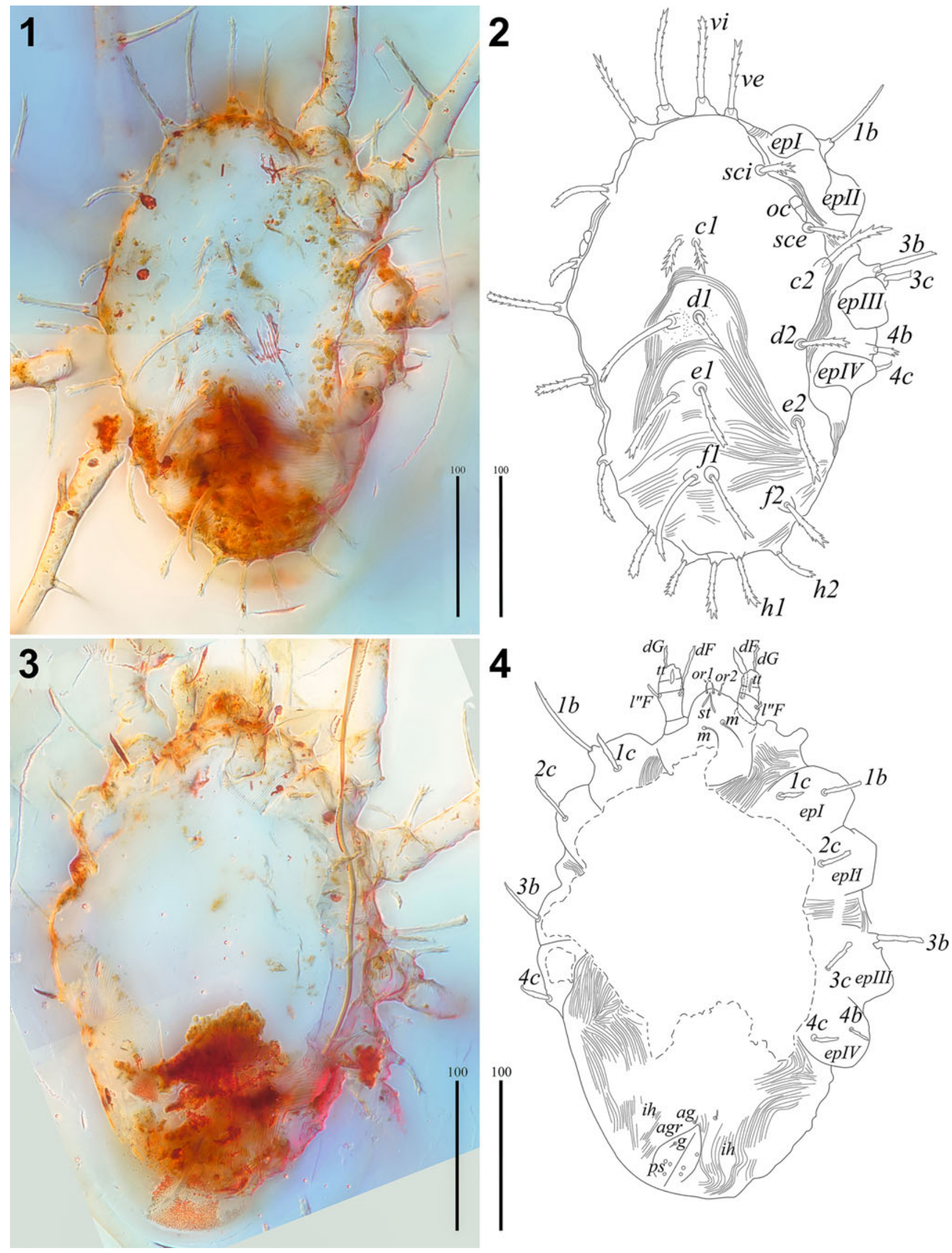


Figure 2. Neophyllobius electrus $n$. sp. (SMNG 07/36290-78a): (1) layered picture of the body in dorsal view; (2) line drawing interpretation of (1); (3) layered picture of the body in ventral view; (4) line drawing interpretation of (3). $1 b, 1 c, 2 c, 3 b, 3 c, 4 b, 4 c=$ epimeral setae; $a g=$ aggenital seta; $a g r=$ anogenital area; $c 1, c 2=$ idiosomal setae of row $\mathrm{C} ; d 1, d 2=$ idiosomal setae of row $\mathrm{D} ; d F=$ dorsal seta of palpfemur; $d G=$ dorsal seta of palpgenu; $e 1, e 2=$ idiosomal setae of row $\mathrm{E} ; e p I-I V=$ epimera of legs I-IV; $f 1, f 2=$ idiosomal setae of row F; $g=$ genital seta; $h 1, h 2=$ idiosomal setae of row $\mathrm{H} ; i h=$ cupule; $m=$ subcapitular medial setae; $l^{\prime \prime} F=$ lateral seta of palpfemur; oc = eyes; orl, or $2=$ oral setae; $p s=$ pseudanal setae; $s c i, s c e=$ scapular setae of prodorsum, $s t=$ cheliceral stylets; $t t=$ palptibia + palptarsus; $v i, v e=$ vertical setae of prodorsum. Scale bars $=100 \mu \mathrm{m}$.

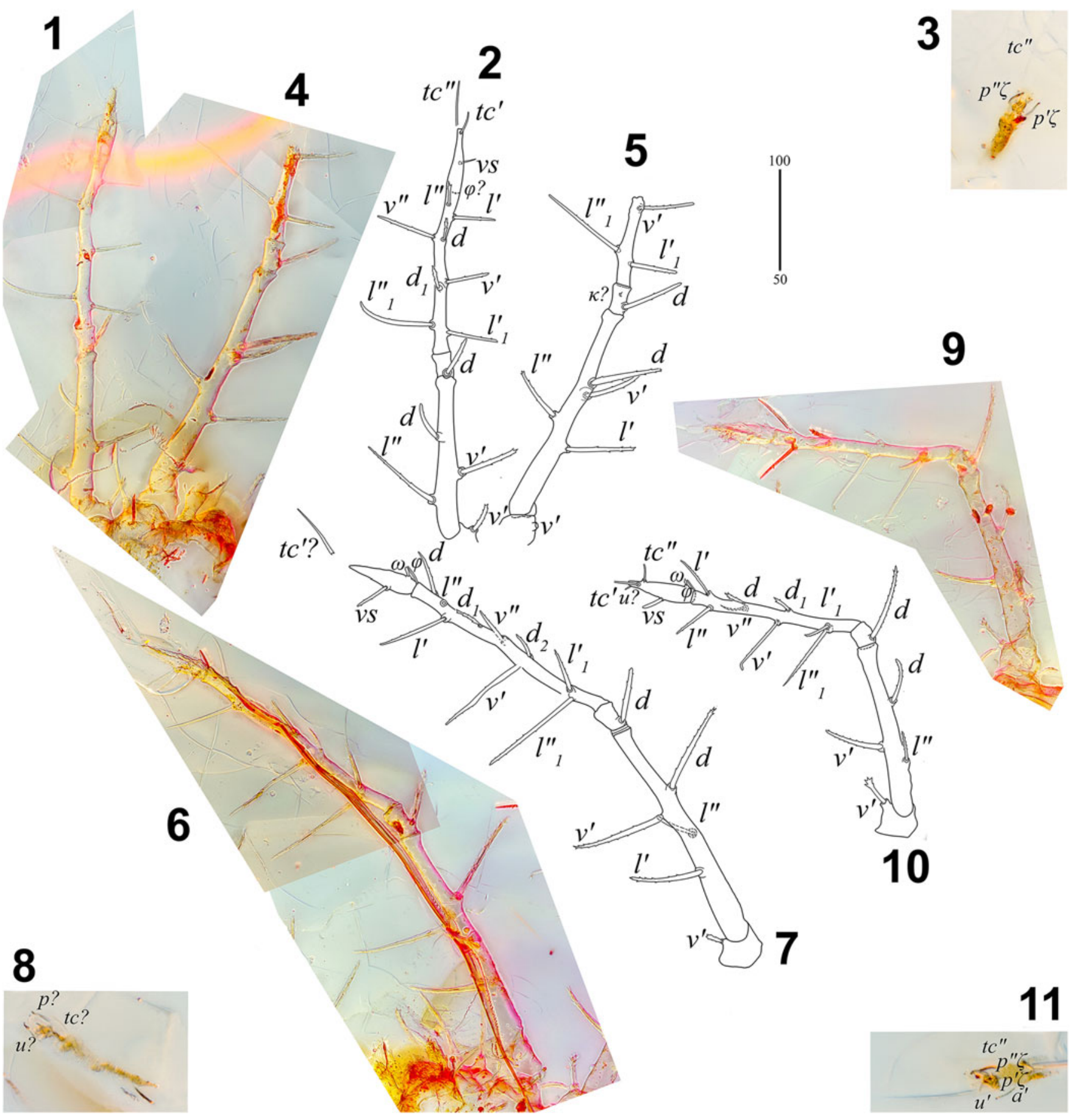

Figure 3. Neophyllobius electrus n. sp. (SMNG 07/36290-78): (1) layered picture of left leg II (SMNG 07/36290-78a); (2) line drawing interpretation of 1; (3) tarsus of left leg II (SMNG 07/36290-78b); (4) layered picture of left leg I (SMNG 07/36290-78a); (5) line drawing interpretation of (4); (6) layered picture of right leg I (SMNG 07/36290-78a); (7) line drawing interpretation of (6); (8) tarsus of right leg I (SMNG 07/36290-78b); (9) layered picture of right leg II (SMNG 07/36290-78a); (10) line drawing interpretation of (9); (11) tarsus of right leg II (SMNG 07/36290-78b). $a=$ anterolateral seta; $d, d_{l}, d_{2}=$ dorsal seta; $l$, $l_{1}=$ lateral seta; $p \zeta=$ eupathidial proral seta; $t c=$ tectal seta; $u=$ unguinal seta; $v=$ ventral seta; $v s=$ midventral seta of tarsus; $\kappa=$ minute genual seta; $\varphi=$ tibial solenidion; $\omega=$ tarsal solenidion; ${ }^{\prime}=$ anterior; $^{\prime \prime}=$ posterior. $(\mathbf{1}, \mathbf{2}, \mathbf{4 - 7 , 9}, \mathbf{1 0})$ Scale bar $=100 \mu \mathrm{m} ;(\mathbf{3}, \mathbf{8}, \mathbf{1 1})$ scale bar $=50 \mu \mathrm{m}$. 


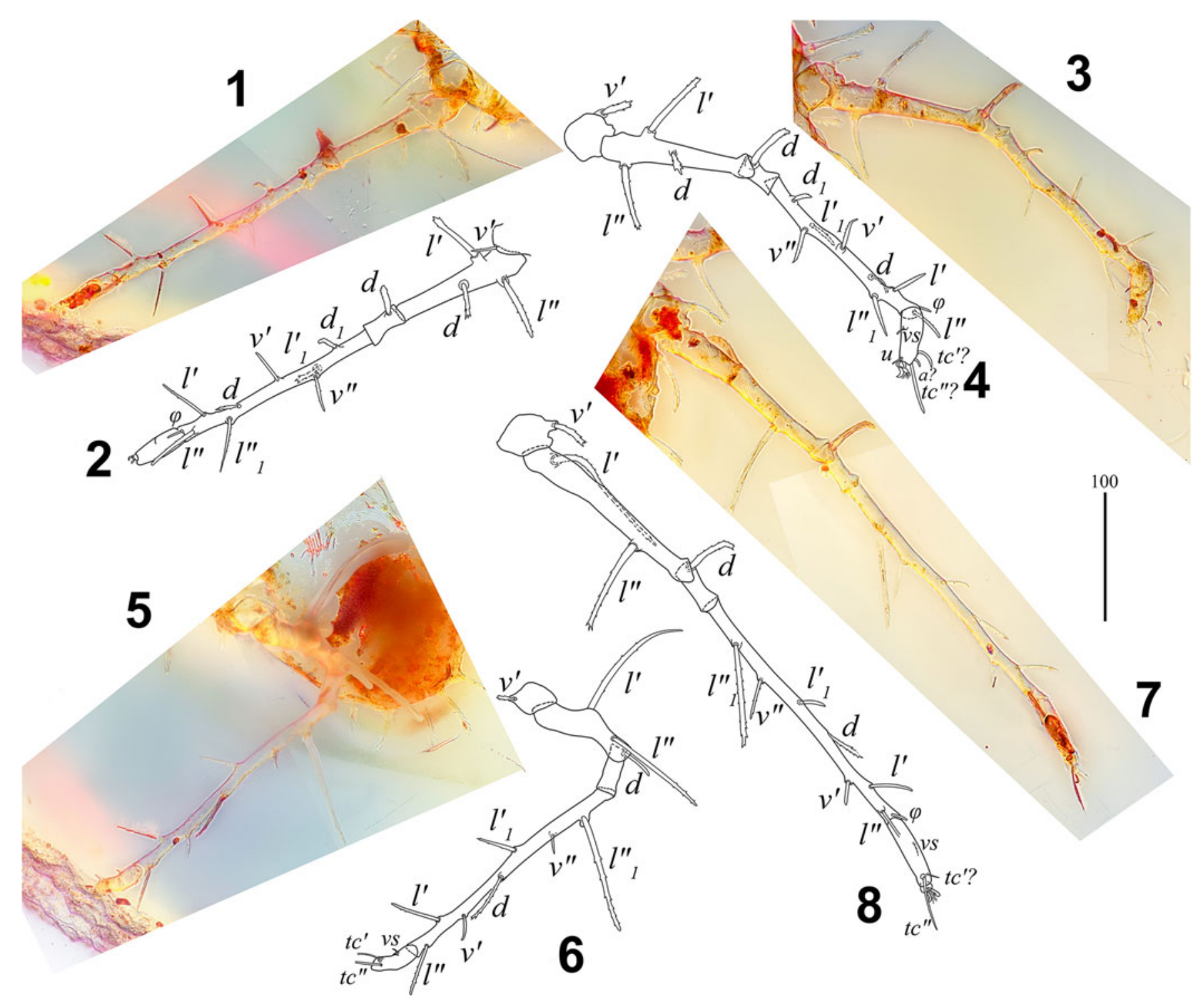

Figure 4. Neophyllobius electrus $\mathrm{n}$. sp. (SMNG 07/36290-78a): (1) layered picture of left leg III; (2) line drawing interpretation of (1); (3) layered picture of right leg III; (4) line drawing interpretation of (3); (5) layered picture of left leg IV; (6) line drawing interpretation of (5); (7) layered picture of right leg IV; (8) line drawing interpretation of (7). $a=$ anterolateral seta; $d, d_{1}=$ dorsal seta; $l, l_{1}=$ lateral seta; $t c=$ tectal seta; $u=$ unguinal seta; $v=$ ventral seta; $v s=$ midventral seta of tarsus; $\varphi=$ tibial solenidion; ' = anterior; " = posterior. Scale bar $=100 \mu \mathrm{m}$.

smooth genital setae $g$ (seta visible on the right side, only the base of seta visible on the left side). Three bases of pseudanal setae $p s 1-3$ present on the right, but only two bases discernible on the left. Oval breaks in the striation situated in the proximity of anogenital region visible (probably areas of simple cupules $i h)$.

Legs (Figs. 3, 4) stilt-like, first and fourth pairs longer than second and third pairs; all setae barbed and situated on tubercles except those on tarsi (smooth and simple except slightly barbed midventral setae $v s$ ). Legs I, the total length of the right one (Fig. 3.6): $548 \mu \mathrm{m}$; left one (Fig. 3.4) deficient (lacking tarsus and half of tibia). Trochanters $51 \mu \mathrm{m}$ long, each with single ventral seta $v^{\prime} 8-12 \mu \mathrm{m}$. Femora elongated 222-223 $\mu \mathrm{m}$, each with four setae, from distal to proximal, $d 70-90 \mu \mathrm{m} ; v^{\prime} 66-88 \mu \mathrm{m}$; $l^{\prime \prime} 41-54 \mu \mathrm{m} ; l^{\prime}$ 67-71 $\mu \mathrm{m}$. Genua 30-37 $\mu \mathrm{m}$, each with single seta $d 51-60 \mu \mathrm{m}$ situated on proximal third, probably a minute seta $\kappa$ on the left one present. Right tibia elongated $206 \mu \mathrm{m}$, with nine setae, from distal to proximal, $d 41 \mu \mathrm{m}$; $l^{\prime \prime}$ (only base visible), $l^{\prime} 65 \mu \mathrm{m} ; d_{1} 29 \mu \mathrm{m} ; v^{\prime \prime} 36 \mu \mathrm{m} ; v^{\prime} 86 \mu \mathrm{m} ; d_{2}$ $22 \mu \mathrm{m} ; l^{\prime}{ }_{1} 49 \mu \mathrm{m} ; l^{\prime \prime}{ }_{1} 99 \mu \mathrm{m}$; and one rod-like distal solenidion $\varphi 19 \mu \mathrm{m}$; left one incomplete $(91 \mu \mathrm{m})$ with three setae $\nu^{\prime} 59 \mu \mathrm{m}$; $l_{1}^{\prime} 51 \mu \mathrm{m}$; and $l^{\prime \prime}{ }_{1} 89 \mu \mathrm{m}$. Right tarsus $64 \mu \mathrm{m}$, not completely preserved, with one ventral seta $v s$ and one clavate proximal solenidion $\omega$, partially preserved setae $t c^{\prime}$ and at least one $p$ and one $u$. Legs II (Fig. 3.1, 3.9), total lengths $403-429 \mu \mathrm{m}$. Trochanter 42-47 $\mu \mathrm{m}$ with single seta $v^{\prime} 30-32 \mu \mathrm{m}$. Femora elongated 142-177 $\mu \mathrm{m}$, each with three setae, from distal to proximal, $d$ 36-45 $\mu \mathrm{m}, v^{\prime} 55-59 \mu \mathrm{m}$, and $l^{\prime \prime}$ 36-71. Genua 30-31 $\mu \mathrm{m}$, each with single seta $d 48-77 \mu \mathrm{m}$ situated on the proximal third. Tibiae elongated $150-164 \mu \mathrm{m}$, each with eight setae, from distal to proximal, $l^{\prime} 41-42 \mu \mathrm{m} ; l^{\prime \prime} 40 \mu \mathrm{m} ; d 18-19 \mu \mathrm{m}$; $v^{\prime \prime} 55-56 \mu \mathrm{m} ; v^{\prime} 25-44 \mu \mathrm{m} ; d_{1} 22-23 \mu \mathrm{m} l_{1}^{\prime} 30-53 \mu \mathrm{m} ; l^{\prime \prime}{ }_{1}$ 


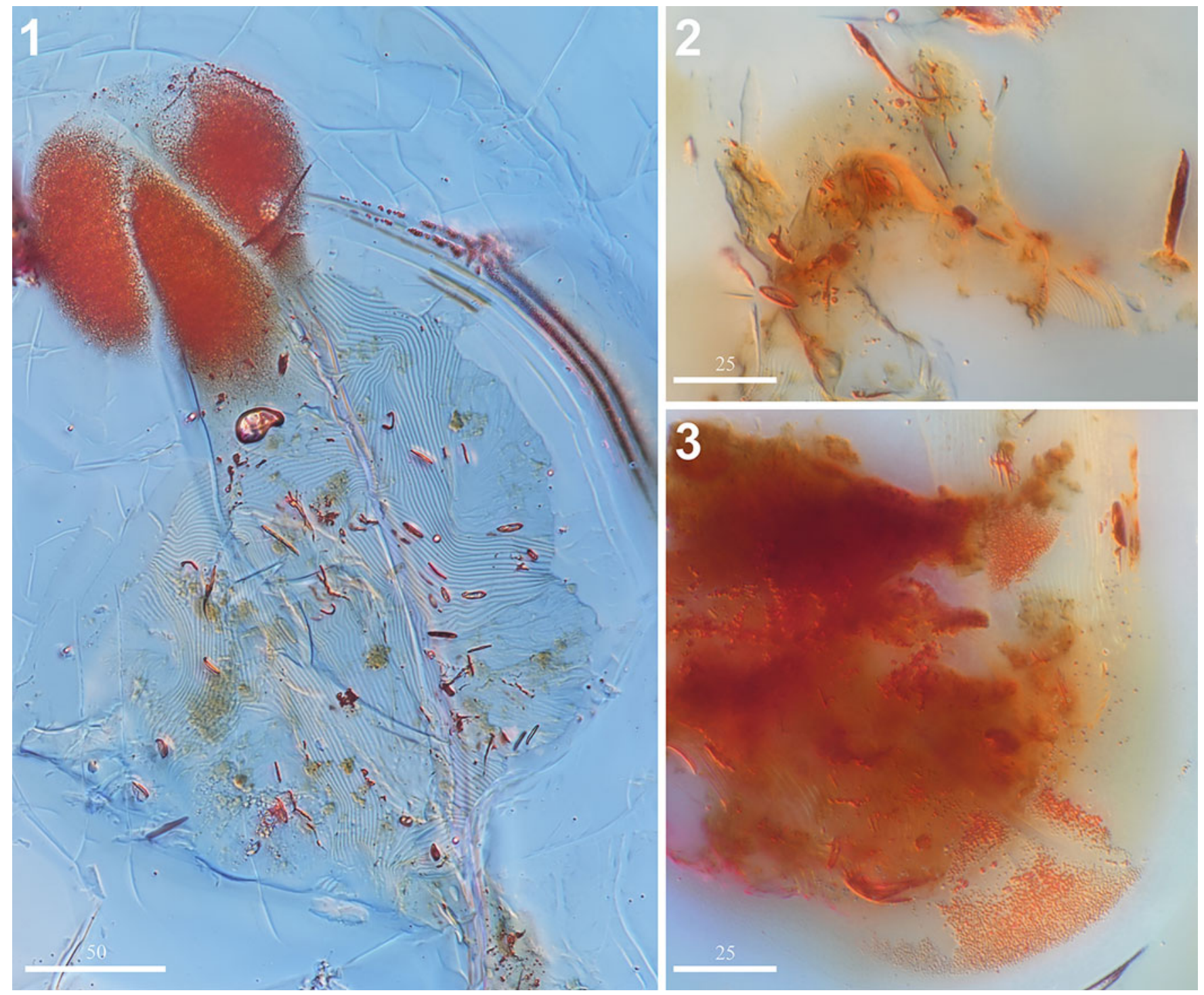

Figure 5. Neophyllobius electrus $\mathrm{n}$. sp. (SMNG 07/36290-78): (1) imprint of ventral cuticle (SMNG 07/36290-78b); (2) gnathosoma in ventral view (SMNG 07/ 36290-78a); (3) opisthosoma in ventral view (SMNG 07/36290-78a). (1) Scale bar $=50 \mu \mathrm{m} ;(\mathbf{2}, \mathbf{3})$ scale bars $=25 \mu \mathrm{m}$.

50-68 $\mu \mathrm{m}$; and one rod-like distal solenidion $\varphi$ 14-18 $\mu \mathrm{m}$. Tarsi 62-64 $\mu \mathrm{m}$, each with one ventral seta $v s$ and tectal setae $(t c)$; eupathidial proral setae $(p \zeta)$ visible on the left tarsus; one unguinal seta $u^{\prime}$, anterolateral $a^{\prime}$, and two eupathidial proral setae $(p \zeta)$ preserved on the right tarsus; one clavate proximal solenidion $\omega$ visible on the right tarsus only. Legs III (Fig. 4.1-4.4), total lengths 345-397 $\mu \mathrm{m}$. Trochanters $35-40 \mu \mathrm{m}$, each with single seta $v^{\prime}$ 23-24 $\mu \mathrm{m}$. Femora elongated $111-116 \mu \mathrm{m}$, each with three setae, from distal to proximal, $d 17-32 \mu \mathrm{m} ; l^{\prime} 50-55 \mu \mathrm{m}$; $l^{\prime \prime} 51-52 \mu \mathrm{m}$. Genua $32-34 \mu \mathrm{m}$, each with single seta $d$ 25-42 $\mu \mathrm{m}$ situated on the proximal third. Tibiae elongated 154 $169 \mu \mathrm{m}$, each with eight setae, from distal to proximal, $l^{\prime \prime}$ $31-36 \mu \mathrm{m} ; l^{\prime}$ 32-42 $\mu \mathrm{m} ; l^{\prime \prime}{ }_{1}$ 32-38 $\mu \mathrm{m} ; d$ 20-21 $\mu \mathrm{m} ; v^{\prime} 25-$ $29 \mu \mathrm{m} ; v^{\prime \prime} 27 \mu \mathrm{m} ; l_{1}^{\prime} 18-21 \mu \mathrm{m} ; d_{1} 14-16 \mu \mathrm{m}$; and one rod-like distal solenidion $\varphi$ 9-12. Tarsi $44-57 \mu \mathrm{m}$, no setae preserved on the left one; on the right one single slightly barbed ventral seta $v s$ and probably ( $t c), a$, and $u$ present; ambulacra (claws + tenant-hair empodium) preserved on each tarsus. Legs
IV (Fig. 4.5-4.8), total lengths 364-485 $\mu \mathrm{m}$. Trochanters 34-42 $\mu \mathrm{m}$ with single ventral seta $v^{\prime} 18-27 \mu \mathrm{m}$. Femora elongated 90-160 $\mu \mathrm{m}$, each with two lateral setae, from distal to proximal, $l^{\prime \prime} 75-89 \mu \mathrm{m}$ and $l^{\prime} 44-95 \mu \mathrm{m}$. Genua $40-43 \mu \mathrm{m}$, each with single seta $d 47 \mu \mathrm{m}$ situated on the proximal third. Tibiae elongated 190-217 $\mu \mathrm{m}$, each with seven setae, from distal to proximal, $l^{\prime \prime} \quad 44-46 \mu \mathrm{m} ; l^{\prime} \quad 36 \mu \mathrm{m} ; v^{\prime} \quad 19-21 \mu \mathrm{m} ; d \quad 29-37 \mu \mathrm{m} ; l^{\prime}{ }_{1} 22-$ $32 \mu \mathrm{m} ; v^{\prime \prime} 17-31 \mu \mathrm{m} ; l^{\prime \prime}{ }_{1} \quad 81-91 \mu \mathrm{m}$; and one rod-like distal solenidion $\varphi 10 \mu \mathrm{m}$. Tarsi $44-58 \mu \mathrm{m}$, each with single ventral seta $v s$ and pair of tectal setae $(t c)$; ambulacra preserved on the right tarsus only. Phanerotaxy formulae (trochanter to tarsus, tarsal setae estimated, $\kappa$ setae not counted): (I) $1-4-1-9(\varphi)-9$ ( $)$; (II) $1-3-1-8(\varphi)-9(\omega)$; (III) $1-3-1-8(\varphi)-7$; (IV) $1-2-1-7$ $(\varphi)-7$.

Etymology.-The specific epithet electrus is an adjective derived from the Latin noun electrum in the nominative, which is translated into amber. 


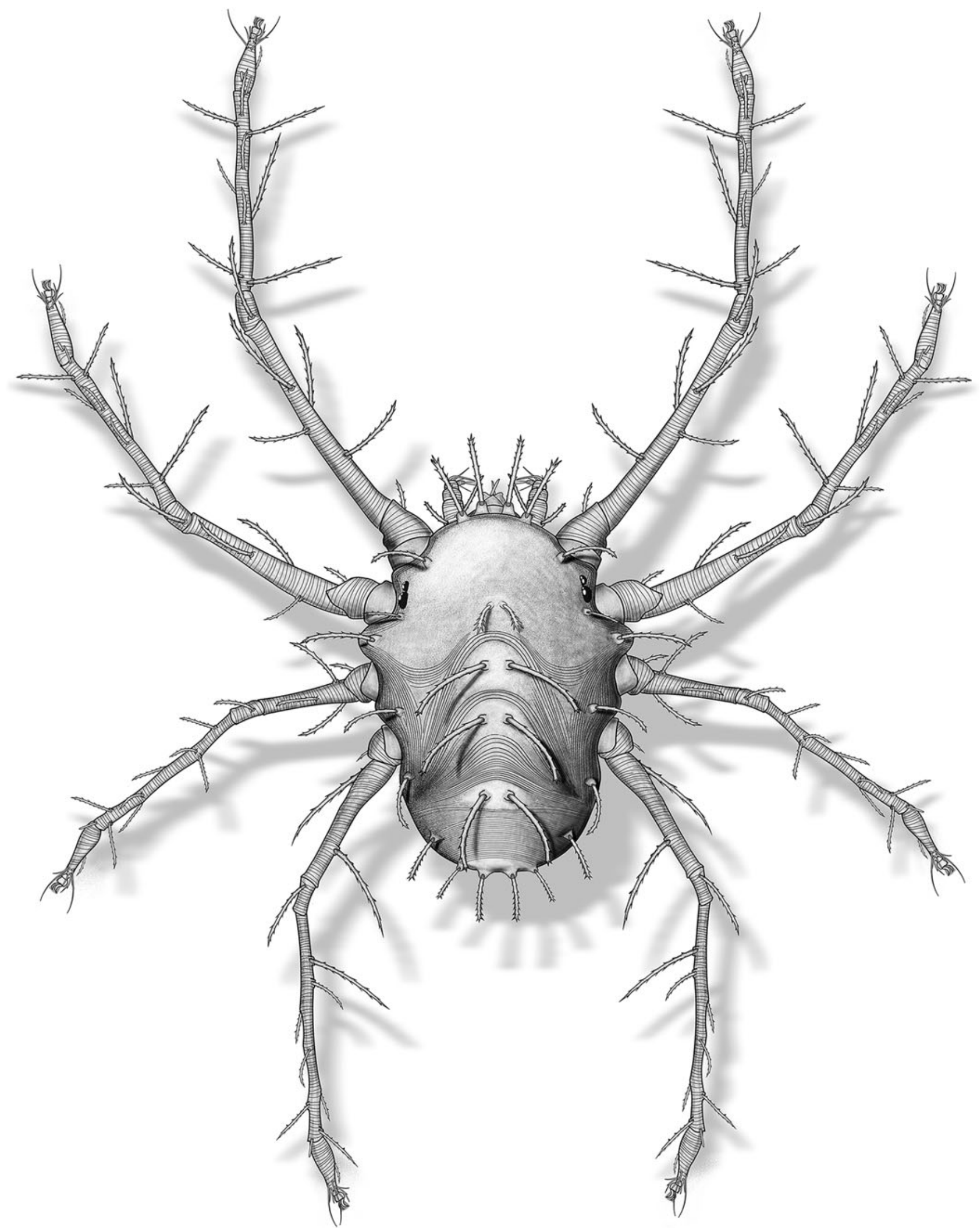

Figure 6. Neophyllobius electrus n. sp., reconstruction of adult female. 
Table 1. Main differences between fossil Neophyllobius species from the Baltic amber. Units $=\mu \mathrm{m}$.

\begin{tabular}{llll}
\hline Character & N. electrus & N. glaesus & N. succineus \\
\hline Body length $\times$ width & $310 \times 183$ & $255 \times 199$ & $250 \times 218$ \\
Prodorsum covers gnathosoma & partially & completely & partially \\
Setae $p d x$ & absent & present & present \\
$v e-$ sci distance & $50-52$ & $29-36$ & 12 \\
Length of setae $c l$ & 24 & $37-42$ & 47 \\
Length of setae $e 1$ & 68 & $42-44$ & 75 \\
Length of setae $h 1$ & $39-40$ & $28-30$ & 64 \\
Midventral tarsal setae $v s$ & one & two & two \\
Tibial setae $d$ versus $l$ and $v$ & shorter & similar length & similar length \\
Setae on femora I-IV & $4-3-3-2$ & $4-3-3-2$ & $4-3-2-2$ \\
Setae on tibiae I-IV & $9-8-8-7$ & $9-8-8-7$ & $8-7-7-6$ \\
\hline
\end{tabular}

Remarks. $-N$. electrus $\mathrm{n}$. sp. is morphologically similar to the extant species N. meyerae Bolland, 1991 by the presence of only one midventral seta on each tarsus I-III. However, it differs from this species by having an additional third seta on femora III, probably $l^{\prime \prime}$ (N. meyerae has only two setae); lack of setae $p d x$ (present in $N$. meyerae); a slightly different idiosomal pattern, especially in terms of $v i-v e$ distance; and significant differences in length between individual pairs within medial and lateral rows of idiosomal setae (there are only slight differences in $N$. meyerae). There are also some similarities between the new species and the Recent camerobiid $N$. panici Bolland, 1991. These two species have only one midventral seta $v s$ on each tarsus IV, four setae on femur I, three setae on femur II, and significant differences in length ratio between the median setae. $N$. electrus n. sp. differs from this species by the presence of only one midventral seta on each tarsus I-III (two setae present in $N$. panici), lack of setae $p d x$ (present in $N$. panici), having additional third setae on femora III, probably $l^{\prime \prime}(N$. panici has only two setae), shorter setae $d$ on genua (in $N$. panici seta $d$ is at least three times longer than the genu), and idiosomal setae barbed (in $N$. panici these setae are nodular). By the presence of three setae on femora III, two setae on femora IV, and the longest setae $d l$ among the idiosomal setae, $N$. electrus $\mathrm{n}$. sp. is also similar to the other extant species $N$. trisetosus De Leon, 1958. The new species differs by the presence of only one midventral seta on each tarsus I-IV ( $N$. trisetosus has two midventral setae on each tarsus I-IV) and by the absence of setae $p d x$ (which are present in $N$. trisetosus).

$N$. electrus n. sp. is morphologically similar to the fossil species N. glaesus n. sp. described herein. Both species have relatively short dorsal setae $d$ of genua I-IV and the same chaetotaxy formulae of femora 4-3-3-2 and tibiae 9-8-8-7. N. electrus differs from $N$. glaesus by the presence of fourteen pairs of idiosomal setae (setae $p d x$ present in $N$. glaesus), ve-sci distance $50-52 \mu \mathrm{m}(29-36 \mu \mathrm{m}$ in N. succineus), gnathosoma partially covered by the prodorsum (in $N$. glaesus prodorsum completely covers it), the presence of only one midventral seta $v s$ on each tarsus (N. glaesus has two setae vs on each tarsus), and shorter dorsal setae $d$ on tibiae than lateral $l$ and ventral $v$ setae (N. glaesus has these setae similar in length). A comparison of all three fossil Neophyllobius species from Baltic amber is summarized in Table 1.

The original sample of amber had a natural fissure filled with air that passed through the inclusion. Hence, to preserve and polish the specimen, the sample was separated into two preparations (see Materials). Nevertheless, the mite imprint in the resin is comparable in quality to modern specimens mounted on microscope slides, even thin striae on the legs and the idiosoma, and clavate tarsal solenidia are clearly visible. Residues of the cuticle, internal organs, and probably food remnants form orange-brown artifacts that hinder the visibility of certain structures such as the anogenital area. Left leg I is incomplete (whole tarsus and a half of tibia missing); those parts were probably lost before embedding in the resin. Interestingly, the apotelae of the legs are poorly preserved, so claws as relatively strongly sclerotized rigid structures should be better remained.

\section{Neophyllobius glaesus new species Figures 1.1, 7-13; Table 1}

Holotype.-Adult female (Fig. 1.1) in two polished pieces of amber. One piece contains an almost complete specimen, and it is placed in a tube with a thymol aqueous solution (GPIH 4995a). Another contains the incomplete left tarsus II (Fig. 12.3) and is embedded in epoxy resin between two round glass coverslips (GPIH 4995b). Type material is deposited in GPIH under collection number GPIH 4995. See Zmudzinski (2020b) for original series of pictures of the specimen.

Diagnosis.-Fifteen pairs of idiosomal barbed setae present (a pair of $p d x$ present). Setae vi and ve on anterior margin of prodorsum directed forward; prodorsum rectangular and covers gnathosoma from above. All idiosoma setae similar in length (except $f 2$ and $h l, h 2$, which are slightly shorter). Setae $d$ on genua I-IV barbed and relatively short (I, 37-48 $\mu \mathrm{m}$; II, 32-35 $\mu \mathrm{m}$; III, 26-32 $\mu \mathrm{m}$; IV, 48-50 $\mu \mathrm{m}$ ). Each of tarsi I-IV with two midventral setae $v s_{1-2}$. Leg phanerotaxy formulae (trochanter to tarsus, tarsal setae estimated, $\kappa$ setae not counted): (I) $1-4-1-9(\varphi)-10(\omega)$; (II) $1-3-1-8(\varphi)-10(\omega)$; (III) $1-3-1-8(\varphi)-8$; (IV) $1-2-1-7(\varphi)-8$.

Occurrence.-Single inclusion within the sample of Baltic amber, middle Eocene 48-38 Ma (Weitschat and Wichard, 2002).

Description of inclusion.-Gnathosoma (Fig. 12.2) situated ventrally on the idiosoma, between epimera I, wholly covered from above by anterior prodorsum, $46 \mu \mathrm{m}$ long (measured from its base to the tip of the infracapitulum) and $48 \mu \mathrm{m}$ wide basally. Stylophore stumpy, peritremes poorly visible, and cheliceral stylets indiscernible due to position of gnathosoma and the fossilized body remains. Subcapitulum slightly striated, with simple medial subcapitular setae: $m$ (13-15 $\mu \mathrm{m}$ long; distance $m-m 22 \mu \mathrm{m}$ ) situated on its middle third, and a pair of short oral setae or on the tip of the infracapitulum, another pair of oral setae indiscernible. Palps directed downward, their total length 30-34 $\mu \mathrm{m}$. Individual articles hardly visible, best-visible palpfemora and sclerotized structures (most probably tibial setae and claw + tarsus). Palpfemora, each with dorsal setae $d$ $24 \mu \mathrm{m}$ and lateral setae $l^{\prime \prime} 9-13 \mu \mathrm{m}$ visible on the right article. Palpgenua with dorsal setae $d 19 \mu \mathrm{m}$. 


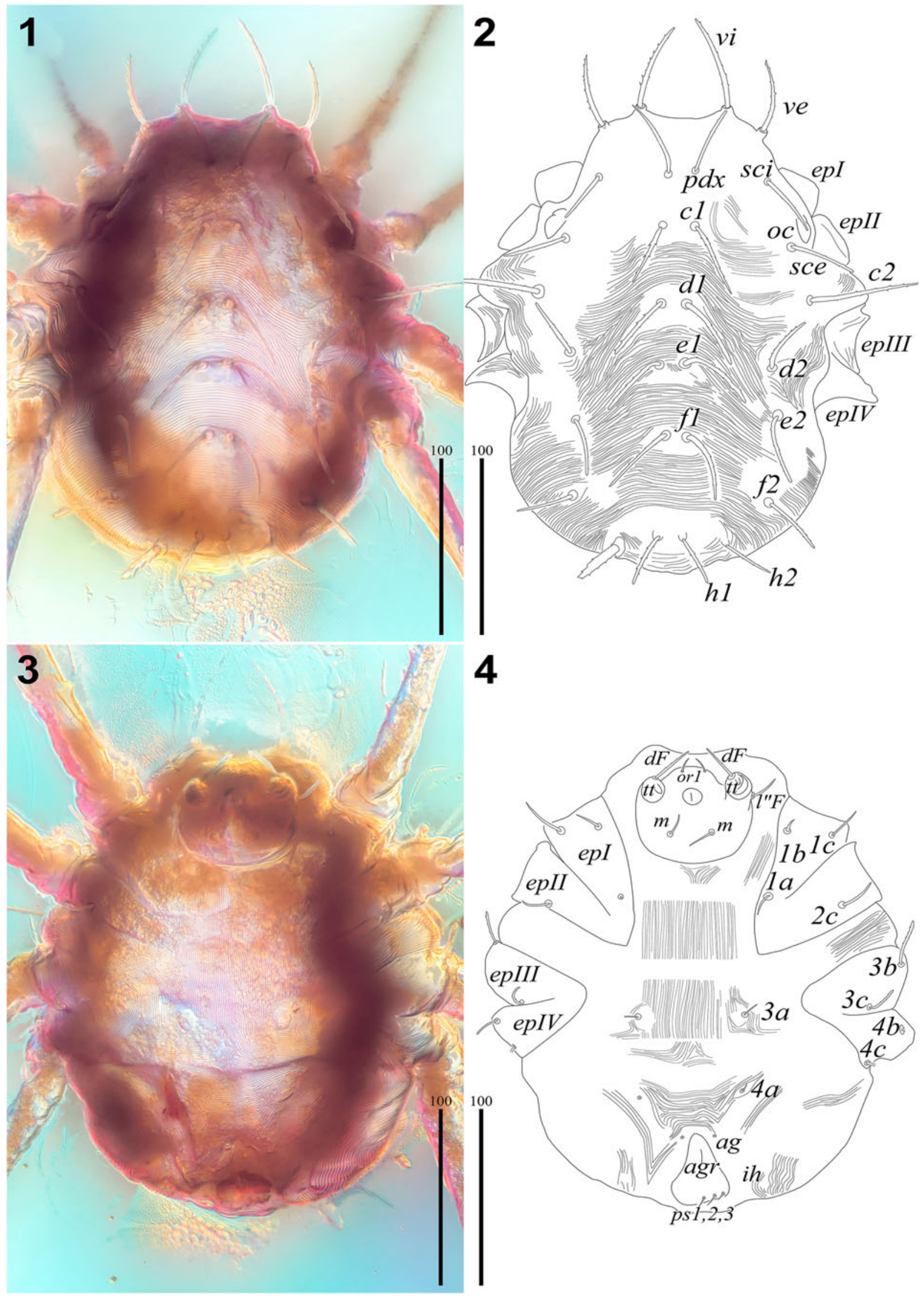


Figure 7. Neophyllobius glaesus n. sp. (GPIH 4995a): (1) layered picture of the body in dorsal view; (2) line drawing interpretation of (1); (3) layered picture of the body in ventral view; (4) line drawing interpretation of (3). $1 a-c, 2 c, 3 a-c, 4 a-c=$ epimeral setae; $a g=$ aggenital seta; $a g r=$ anogenital area; $c 1, c 2=$ idiosomal setae of row $\mathrm{C} ; d 1, d 2=$ idiosomal setae of row $\mathrm{D} ; d F=$ dorsal seta of palpfemur; $e 1, e 2=$ idiosomal setae of row $\mathrm{E} ; e p I-I V=$ epimera of legs $\mathrm{I}-\mathrm{IV} ; f 1, f 2=$ idiosomal setae of row F; $h 1, h 2=$ idiosomal setae of row $\mathrm{H} ; i h=$ cupule; $m=$ subcapitular medial setae; $l^{\prime \prime} F=$ lateral seta of palpfemur; $o c=$ eyes; $o r l=$ oral seta; $p d x=$ fifteenth pair of idiosomal setae on prodorsum; $p s 1-3=$ pseudanal setae; $s c i, s c e=$ scapular setae of prodorsum; $t t=$ palptibia + palptarsus; $v i, v e=$ vertical setae of prodorsum. Scale bars $=100 \mu \mathrm{m}$.

Idiosoma (Fig. 7) oval, $255 \mu \mathrm{m}$ long and $199 \mu \mathrm{m}$ wide (measured at the level of the bases of setae $c 2$ ), opisthosoma wider than prodorsum. Cuticle striated, except anterior prodorsum, around the setae $c l, d l, e l$, and $f l$ and epimeral (coxal) fields. Dorsal idiosoma with fifteen pairs of barbed setae set on small cuticular single (not coupled) tubercles. Prodorsum rectangular; anterior margin concave. Setae vi $(49-53 \mu \mathrm{m}$ long; distance $v i-v i 44 \mu \mathrm{m})$ and $v e(41-53 \mu \mathrm{m}$; ve-ve $83 \mu \mathrm{m})$ directed forward. Setae $s c i(31-35 \mu \mathrm{m} ; s c i-s c i 90 \mu \mathrm{m})$ and $s c e$ (34-37 $\mu \mathrm{m} ;$ sce-sce $117 \mu \mathrm{m}$ ) on the lateral margins of prodorsum. Between them, on each side, two eyes present, anterior one $(4 \mu \mathrm{m}$ in diameter) a little smaller than the posterior one $(7.5 \mu \mathrm{m})$. Five pairs of setae of similar length in the central part present: $p d x$ (34-38 $\mu \mathrm{m}$ long; distance $p d x-p d x 14 \mu \mathrm{m})$, $c 1$ (37-42 $\mu \mathrm{m}$ long; distance $c l-c l 21 \mu \mathrm{m}), d l(41 \mu \mathrm{m} ; d l-d l$ $16 \mu \mathrm{m}), e 1$ ( $42-44 \mu \mathrm{m} ; e l-e l 17 \mu \mathrm{m})$, and $f 1$ ( $41 \mu \mathrm{m} ; f 1-f 113$ $\mu \mathrm{m})$. Lateral setae $c 2(52-53 \mu \mathrm{m} ; c 2-c 2143 \mu \mathrm{m}), d 2(33 \mu \mathrm{m}$; $d 2-d 2105 \mu \mathrm{m}), e 2(42-54 \mu \mathrm{m} ; e 2-e 2103 \mu \mathrm{m})$, and $f 2(24-33$ $\mu \mathrm{m} ; f 2-f 2113 \mu \mathrm{m}$ ) situated closer to the center (not on the margins). Setae $h l(28-30 \mu \mathrm{m}, h l-h l 16 \mu \mathrm{m})$ situated on moresclerotized unstriated cuticle, and $h 2(23-25 \mu \mathrm{m} ; h 2-h 259$ $\mu \mathrm{m})$ terminate the idiosoma; left seta $h 2$ hypertrophied (Fig. 12.4; see Discussion). Extremities of epimera visible from the dorsal side; the dorsolateral cuticle passes between second and third epimera. Supplementary distances: vi-ve

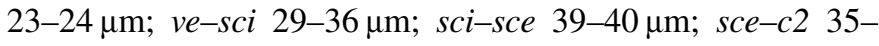
$36 \mu \mathrm{m} ; v i-p d x 34-37 \mu \mathrm{m} ; p d x-c 1$ 31-36 $\mu \mathrm{m} ; c 1-c 2$ 73-80 $\mu \mathrm{m}$;

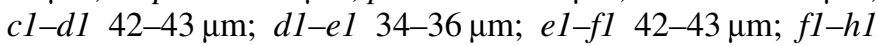

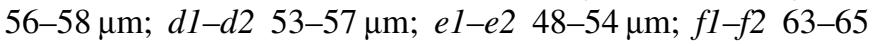
$\mu \mathrm{m} ; h 1-h 223 \mu \mathrm{m} ; f 2-h 2 \quad 35-40 \mu \mathrm{m} ; e 2-f 2 \quad 50-51 \mu \mathrm{m} ; d 2-e 2$ $29 \mu \mathrm{m} ; c 2-d 238-43 \mu \mathrm{m}$. Coxal fields grouped into two areas: I partially fused with II, and coxal field III partially fused with IV. Epimeral setae slightly barbed and set on small cuticular protuberances: $1 a 13 \mu \mathrm{m}$ long (only the base of seta visible on the right side); $1 b \quad 11-14 \mu \mathrm{m} ; 1 c 19-21 \mu \mathrm{m} ; 2 c 18-25 \mu \mathrm{m} ; 3 a$

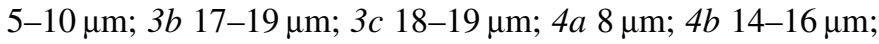
$4 c 17 \mu \mathrm{m}$; setae $3 a$ and $4 a$ situated in the intercoxal region, distance $3 a-3 a 49 \mu \mathrm{m} ; 4 a-4 a 55 \mu \mathrm{m}$. The anogenital area (Fig. 12.1) visible, but hard to discern its details. A pair of short, simple, smooth aggenital setae ag situated just above its anterior margin. Genital valves with one pair of short, simple, smooth genital setae $g$ (seta visible on the right side, only base of seta visible on the left side). Three bases of pseudanal setae ps 1-3 present on the right valve but only two bases discernible on the left valve. Oval breaks in the striation situated in the proximity of anogenital region visible (probably areas of simple cupules $i h$ ).

Legs (Figs. 8-11) stilt-like, first and fourth pairs longer than second and third pairs, all setae barbed and situated on small tubercles except those on tarsi (simple and smooth except slightly barbed midventral setae vs). Legs I (Fig. 8), the total length of the right one $412 \mu \mathrm{m}$; left one deficient (lacking tarsus and a half of tibia). Trochanters 33-36 $\mu \mathrm{m}$ long, each with single ventral seta $v^{\prime} 6-10 \mu \mathrm{m}$. Femora elongated $157-162 \mu \mathrm{m}$, each with four setae, from distal to proximal, $d 48-49 \mu \mathrm{m} ; l^{\prime} 25-27$ $\mu \mathrm{m} ; l^{\prime}{ }_{1} 25-38 \mu \mathrm{m} ; b v^{\prime \prime}$ 9-12 $\mu \mathrm{m}$. Genua 34-38 $\mu \mathrm{m}$, each with single seta $d 37-48 \mu \mathrm{m}$ situated on the proximal third. Right tibia elongated $147 \mu \mathrm{m}$, with nine setae, from distal to proximal, $d 42 \mu \mathrm{m} ; l^{\prime} 39 \mu \mathrm{m} ; l^{\prime \prime} 44 \mu \mathrm{m} ; v^{\prime \prime} 43 \mu \mathrm{m} ; d_{1} 46 \mu \mathrm{m} ; v^{\prime} 36-44 \mu \mathrm{m}$; $d_{2} 34-41 \mu \mathrm{m} ; l^{\prime \prime}{ }_{1} 33-36 \mu \mathrm{m} ; l^{\prime}{ }_{1} 40-42 \mu \mathrm{m}$; and one rod-like distal solenidion $\varphi 21 \mu \mathrm{m}$; left one incomplete. Right tarsus $37 \mu \mathrm{m}$ with the complete set of setae visible: tectal $(t c)$, eupathidial proral $(p \zeta)$, anterolateral $(a)$, unguinal $(u)$, midventral $v s_{1-2}$, and one proximal clavate solenidion $\omega$; apotele (ambulacral stalk, claws, tenant-hair empodium) preserved. Legs II (Fig. 9), the total length of the right one $300 \mu \mathrm{m}$, left one incomplete, tarsus and part of tibia as a separate preparation (GPIH 4995b). Trochanter $29 \mu \mathrm{m}$ with single seta $v^{\prime} 9-12 \mu \mathrm{m}$. Femora elongated 114-116 $\mu \mathrm{m}$, each with three setae, from distal to proximal, $d$ 38-40 $\mu \mathrm{m} ; l^{\prime} 21-27 \mu \mathrm{m}$; and $b v^{\prime \prime} 15 \mu \mathrm{m}$. Genua $25-27 \mu \mathrm{m}$, each with single seta $d 32-35 \mu \mathrm{m}$ situated on the proximal third. Tibiae elongated $86 \mu \mathrm{m}$, each with eight setae, from distal to proximal, $d 39 \mu \mathrm{m} ; l^{\prime} 21 \mu \mathrm{m} ; l^{\prime \prime} 28 \mu \mathrm{m} ; v^{\prime} 41 \mu \mathrm{m} ; v^{\prime \prime} 20 \mu \mathrm{m} ; d_{l}$ $31 \mu \mathrm{m} ; l^{\prime \prime}{ }_{1} 35-49 \mu \mathrm{m} ; l^{\prime}{ }_{1} 23-26 \mu \mathrm{m}$; and one rod-like distal solenidion $\varphi 12 \mu \mathrm{m}$. Right tarsus $45 \mu \mathrm{m}$, with two midventral setae $v s_{1}$ and $v s_{2}$, tectal $(t c)$, unguinal $(u)$, at least one anterolateral $(a)$ and one proral $(p)$ and one proximal clavate solenidion $\omega+$ complete apotele; on the left tarsus tectal and midventral setae preserved along with apotele. Legs III (Fig. 10), total lengths 383-399 $\mu \mathrm{m}$. Trochanters 32-34 $\mu \mathrm{m}$, each with single seta $v^{\prime}$ 14-18 $\mu \mathrm{m}$. Femora elongated $114 \mu \mathrm{m}$, each with three setae, from distal to proximal, $d 32 \mu \mathrm{m} ; l^{\prime} 23-24 \mu \mathrm{m} ; e v^{\prime \prime} 21 \mu \mathrm{m}$. Genua 28-32 $\mu \mathrm{m}$, each with single seta $d 26-32 \mu \mathrm{m}$ situated on the proximal third. Tibiae elongated $163-170 \mu \mathrm{m}$, each with eight setae, from distal to proximal, $l^{\prime} 45 \mu \mathrm{m} ; d$ 39-40 $\mu \mathrm{m} ; l^{\prime \prime} 46-48 \mu \mathrm{m} ; v_{1} 39-41 \mu \mathrm{m} ; v_{2} 36-43 \mu \mathrm{m} ; l^{\prime \prime}{ }_{1} 28-42 \mu \mathrm{m}$; $d_{1} 24-27 \mu \mathrm{m} ; l_{1}, 32 \mu \mathrm{m}$; and one rod-like distal solenidion $\varphi$ $13 \mu \mathrm{m}$. Tarsi $52-53 \mu \mathrm{m}$, each with complete set of setae: $v s_{1-2},(t c),(a),(u)$, and apotele. Legs IV (Fig. 11), total lengths $460 \mu \mathrm{m}$. Each trochanter 31-37 $\mu \mathrm{m}$ with single ventral seta $v^{\prime} 13-16 \mu \mathrm{m}$. Femora elongated 136-146 $\mu \mathrm{m}$, each with two lateral setae, from distal to proximal, $l^{\prime \prime} 24-29 \mu \mathrm{m}$ and $l^{\prime}$ 35-36 $\mu \mathrm{m}$. Genua 30-34 $\mu \mathrm{m}$, each with single seta $d 48-50$ $\mu \mathrm{m}$ situated on the proximal third. Tibiae elongated $191 \mu \mathrm{m}$, each with seven setae, from distal to proximal $l^{\prime} 45 \mu \mathrm{m} ; d$ $34 \mu \mathrm{m} ; l^{\prime \prime} 30 \mu \mathrm{m} ; v_{1} 32 \mu \mathrm{m} ; v_{2} 40 \mu \mathrm{m} ; l^{\prime \prime}{ }_{1} 43 \mu \mathrm{m} ; l^{\prime}{ }_{1} 32 \mu \mathrm{m}$; and one rod-like distal solenidion $\varphi 11 \mu \mathrm{m}$. Tarsi $64 \mu \mathrm{m}$, each with preserved apotele and probably complete set of setae. Phanerotaxy formulae (trochanter to tarsus, tarsal setae estimated, $\kappa$ setae not counted): (I) $1-4-1-9(\varphi)-10(\omega)$; (II) $1-3-1-8(\varphi)-10(\omega)$; (III) $1-3-1-8(\varphi)-8$; (IV) $1-2-1-7$ $(\varphi)-8$. 

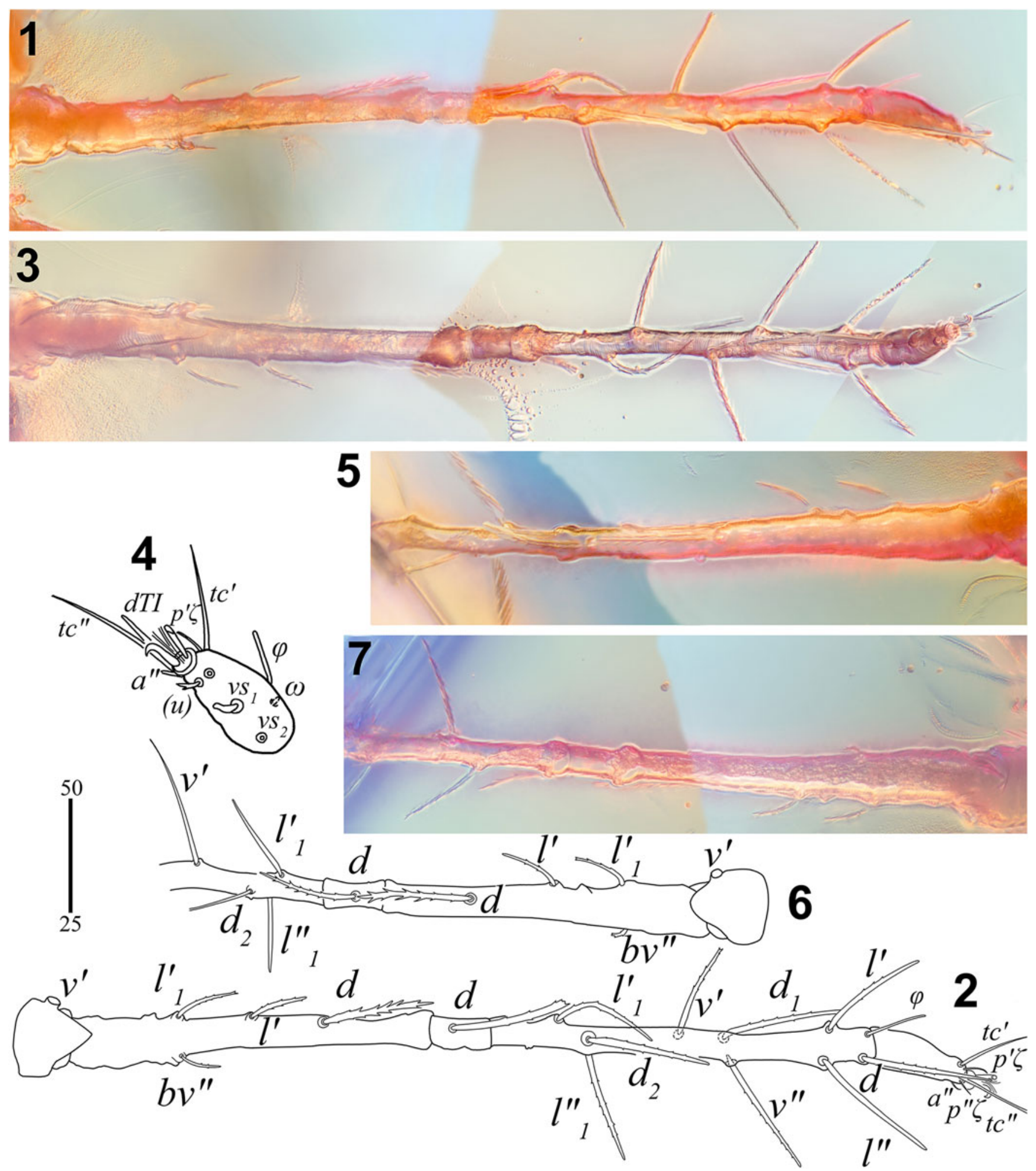

Figure 8. Neophyllobius glaesus n. sp., leg I (GPIH 4995a): (1) layered picture of right one in dorsal view; (2) line drawing interpretation of (1); (3) layered picture of right one in ventral view; (4) line drawing interpretation of right tarsus in ventral view; (5) layered picture of left one in dorsal view; (6) line drawing interpretation of (5); (7) layered picture of left one in ventral view. $a=$ anterolateral seta; $b v=$ basiventral seta of femur; $d, d_{l}, d_{2}=$ dorsal seta; $d T I=$ dorsal seta of right tibia I; $l, l_{l}=$ lateral seta; $p \zeta=$ eupathidial proral seta; $t c=$ tectal seta; $u=$ unguinal seta; $v=$ ventral seta; $v s_{1}, v s_{2}=$ midventral setae of tarsus; $\varphi=$ tibial solenidion; $\omega=$ tarsal solenidion; ' = anterior; " = posterior. (1-3, 5-7) Scale bar $=50 \mu \mathrm{m} ;(\mathbf{4})$ scale bar $=25 \mu \mathrm{m}$. 

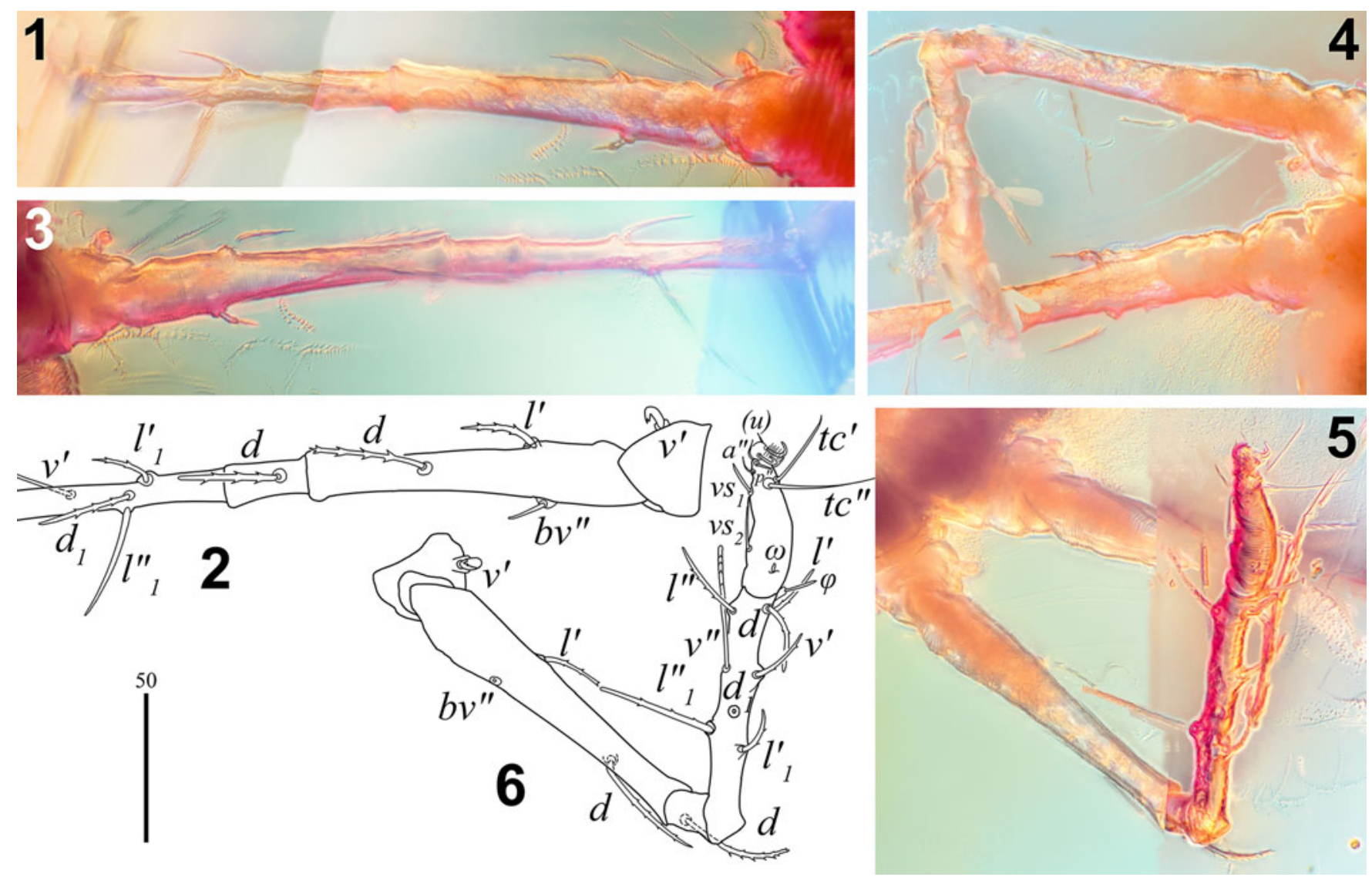

Figure 9. Neophyllobius glaesus $\mathrm{n}$. sp., leg II (GPIH 4995a): (1) layered picture of right one in dorsal view; (2) line drawing interpretation of (1); (3) layered picture of right one in ventral view; (4) layered picture of left one in dorsal view; (5) layered picture of left one in ventral view; (6) line drawing interpretation of (5). $a=$ anterolateral seta; $b v=$ basiventral seta of femur; $d, d_{1}=$ dorsal seta; $l, l_{1}=$ lateral seta; $p=$ proral seta; $t c=$ tectal seta; $u=$ unguinal seta; $v=$ ventral seta; $v s_{1}, v s_{2}=$ midventral setae of tarsus; $\varphi=$ tibial solenidion; $\omega=$ tarsal solenidion; ${ }^{\prime}=$ anterior; ${ }^{\prime \prime}=$ posterior. Scale bar $=50 \mu \mathrm{m}$.

Etymology.-The specific epithet glaesus is an adjective derived from the Latin noun glaesum in the nominative, which is translated into amber.

Remarks. $-N$. glaesus $\mathrm{n}$. sp. is morphologically very similar to the Recent species $N$. hypoleanae Bolland, 1991. Both species have relatively short dorsal setae $d$ of genua I-III; setae $c l$ are shorter and $d l$ longer than interval to setae next behind them; setae $b v^{\prime \prime}$ (most proximal) of femora I are distinctly shorter than setae $d$ (most distal); epimeral setae $1 a-c$ are different in length; number of setae on femora I-IV are 4-3-3-2, respectively; each tarsus of legs I-IV has two midventral setae $v s$; dorsal setae $d$ of palpfemur are only slightly longer than lateral setae $l^{\prime \prime}$. However, $N$. glaesus has short dorsal setae $d$ on genua IV ( $N$. hypoleanae has these setae at least two times longer than the length of the genu); distances between setae ve and $s c i$ are distinctly greater (in $N$. hypoleanae bases of ve are situated just in front of $s c i$ ); setae el $45 \mu \mathrm{m}$ long and $f 141 \mu \mathrm{m}$ are distinctly shorter (these setae in $N$. hypoleanae are $60 \mu \mathrm{m}$ long); and setae $f 1$ do not reach level of bases of setae $h l$ (in $N$. hypoleanae setae $f l$ reach behind bases of setae $h l$ ).

N. glaesus n. sp. is morphologically similar to the fossil species N. succineus Bolland and Magowski, 1990. Both species have a relatively short dorsal setae $d$ of genua I-IV; fifteen pairs of idiosomal setae (setae $p d x$ present) without significant differences in their lengths; two midventral setae $v s$ on each tarsus; and the dorsal setae $d$ of tibiae similar in length to the lateral $l$ and ventral $v$ setae. The new species differs from $N$. succineus by the presence of three setae on femora III ( $N$. succineus has only two of them); chaetotaxy formulae of tibiae I-IV is 9-88-7 (8-7-7-6 in N. succineus); distinctly shorter idiosomal setae $e 142-44 \mu \mathrm{m}$ and $h l(28-30 \mu \mathrm{m})(75$ and $64 \mu \mathrm{m}$, respectively, in N. succineus); distance ve-sci $29-36 \mu \mathrm{m}(12 \mu \mathrm{m}$ in $N$. succineus); and gnathosoma wholly covered by the prodorsum (in N. succineus prodorsum covers it partially). A comparison of all three fossil Neophyllobius species from Baltic amber is summarized in Table 1.

Unlike the inclusion of $N$. electrus, almost the entire individual was preserved inside the preparation. The cuticle imprint is translucent, especially on the legs and in the middle of the idiosoma. Residues of the cuticle, internal organs, and probably food remains form brown artifacts within the inclusion. Their highest concentration occurs on the edges of the idiosoma forming a dense border. This makes it difficult to interpret some structures, especially on the ventral opisthosoma. The piece containing the tarsus and part of the tibia of left leg II broke off and was embedded in epoxy resin to preserve such minute amber fragment. Left tarsus I had already been cut or polished in the sample. 

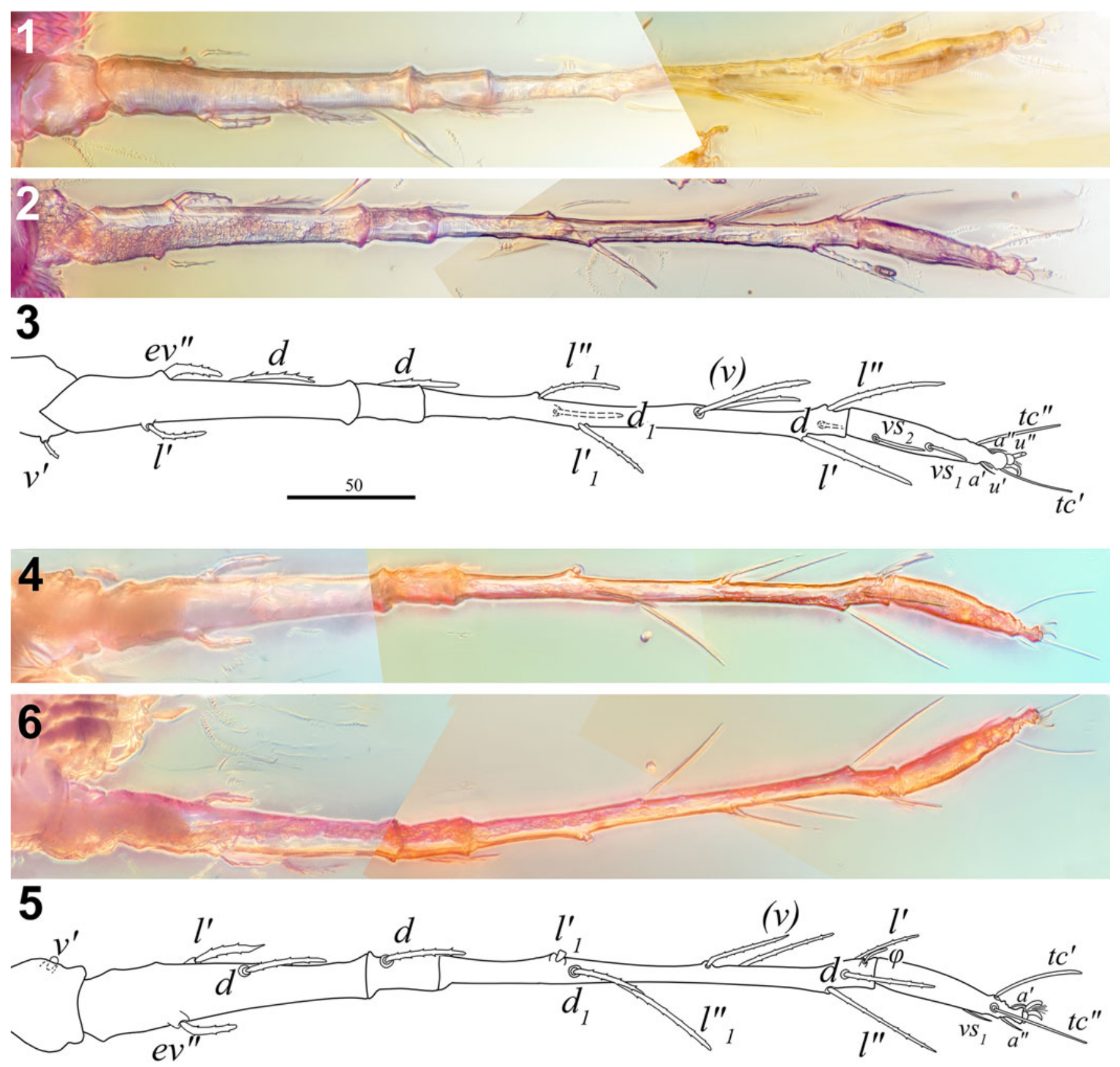

Figure 10. Neophyllobius glaesus n. sp., leg III (GPIH 4995a): (1) layered picture of left one in dorsal view; (2) layered picture of left one in ventral view; (3) line drawing interpretation of (2); (4) layered picture of right one in dorsal view; (5) line drawing interpretation of (4); (6) layered picture of right one in ventral view. $a=$ anterolateral seta; $d, d_{1}=$ dorsal seta; $e v=$ basiventral seta of femur; $l, l_{1}=$ lateral seta; $t c=$ tectal seta; $u=$ unguinal seta; $v=$ ventral seta; $v s_{1}, v s_{2}=$ midventral setae of tarsus; $\varphi=$ tibial solenidion; ' $=$ anterior; ", posterior. Scale bar $=50 \mu \mathrm{m}$.

\section{Discussion}

Common remarks for studied inclusions.-The most recent and valid diagnosis of Neophyllobius has been proposed by Fan and Walter (2006). There is little doubt that the fossil specimens belong to this genus. Although the preservation does not reveal an exact number of peritremal loops, there is at least one in each inclusion because some peritremal structures are visible microscopically. Palptrochanters are nude, palpfemora have two setae on each, and each palpgenu has one seta. Idiosoma bears 14 or 15 pairs of setae. Genital valves have one pair of setae $g$. Anal valves have probably three pairs of pseudanal setae $p s 1-3$. Solenidion $\omega$ is present on each basal half of tarsi I and II. Phanerotaxies of legs are also typical, as in Recent representatives of Neophyllobius.

There is noticeable sexual dimorphism in the family Camerobiidae (already present in nymphs, see Bolland, 2001). As in other raphignathoid families, males have a sclerotized aedeagus, and the genital opening is situated terminally or dorsoterminally. In addition, there are two solenidia $\varphi$ on each tibia I-II, and tarsal solenidia $\omega$ are enlarged and/or elongated. The lack of these features excludes the possibility that the specimens 

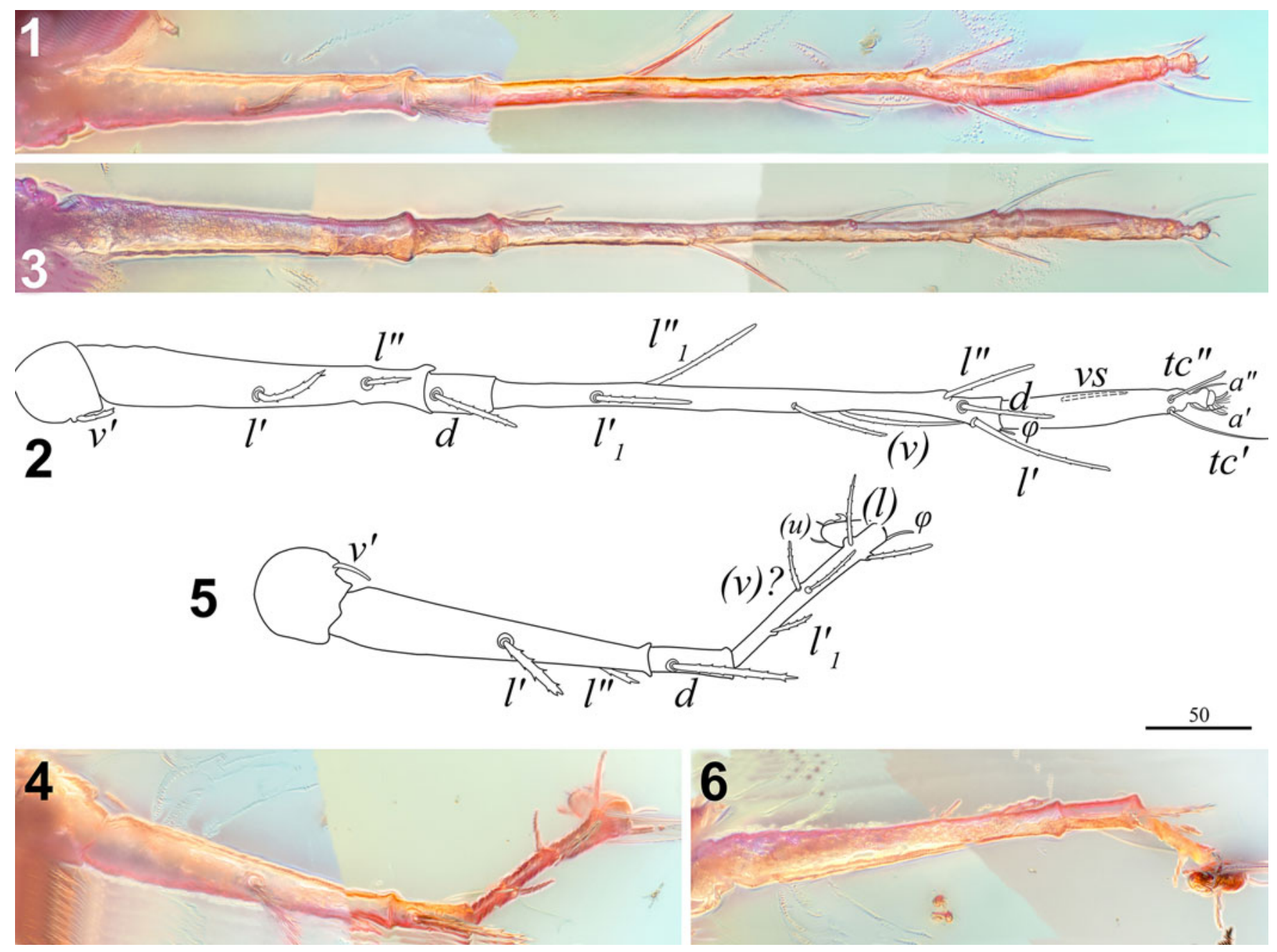

Figure 11. Neophyllobius glaesus n. sp., leg IV (GPIH 4995a): (1) layered picture of left one in dorsal view; (2) line drawing interpretation of (1); (3) layered picture of left one in ventral view; (4) layered picture of right one in dorsal view; (5) line drawing interpretation of (4); (6) layered picture of right one in ventral view. $a=$ anterolateral seta; $d=$ dorsal seta; $l, l_{l}=$ lateral seta; $t c=$ tectal seta; $u=$ unguinal seta; $v=$ ventral seta; $v s=$ midventral seta of tarsus; $\varphi=$ tibial solenidion; '= anterior; " = posterior. Scale bar $=50 \mu \mathrm{m}$.

are males. There are also other sex differences such as the length and position of some leg setae, but they are objectively comparable only if there are two sexes available to study. Camerobiid protonymphs are easily distinguished by the absence of setae on the epimera of legs IV and the nude trochanters IV (seta $v^{\prime}$ not developed yet). These setae are present on the studied specimens. Bolland (1983) stated for the first time that there are two nymphal stases within the family. However, deutonymphs are more difficult to distinguish from adults without reference material of all stases. Deutonymphs have generally longer setae $d$ on the genua. Specimens of each new fossil species have relatively short genual setae, were found solely (larvae and nymphs are more commonly found in small aggregations), and probably have well-developed genital valves and complete chaetotaxy. Hence, the specimens are considered in this work as adult females, which seems to be the most probable determination of stase and sex. It is important for the reader to be aware of the difficulty of interpreting the fossil material, especially if it is present only in the form of sole individuals of rare mite groups.
Asymmetric hypertrophy of seta $\mathrm{h} 2$ in N. glaesus.-Mostly neglected, François Grandjean's works on deviations and their possible evolutionary significance (summarized and extended in Grandjean, 1971, 1972, 1973 but unfinished) echo even with individual discoveries, as is the case with the inclusion of N. glaesus n. sp. According to Grandjean, deviations can be divided into vertitions, which are important in evolutionary terms and reflect the changes that may occur in future generations permanently, and anomalies, which are more rare, random changes that are not of evolutionary significance (Grandjean, 1971). Deviations are most often asymmetrical and include the absence of some idionymous organ (any holotrichous seta is an example of such), its doubling, change of size, or different location. Other scholars have also studied morphological abnormalities, mostly in terms of teratological singularities but also in the context of regulatory genes (e.g., Southcott, 1997; Weigmann, 2010; Bingül et al., 2017). Abnormalities occurring among populations of Tycherobius stramenticola Bolland, 1986 and T. polonicus Bolland, 1986, mostly in the form of asymmetrical absence of setae, were 


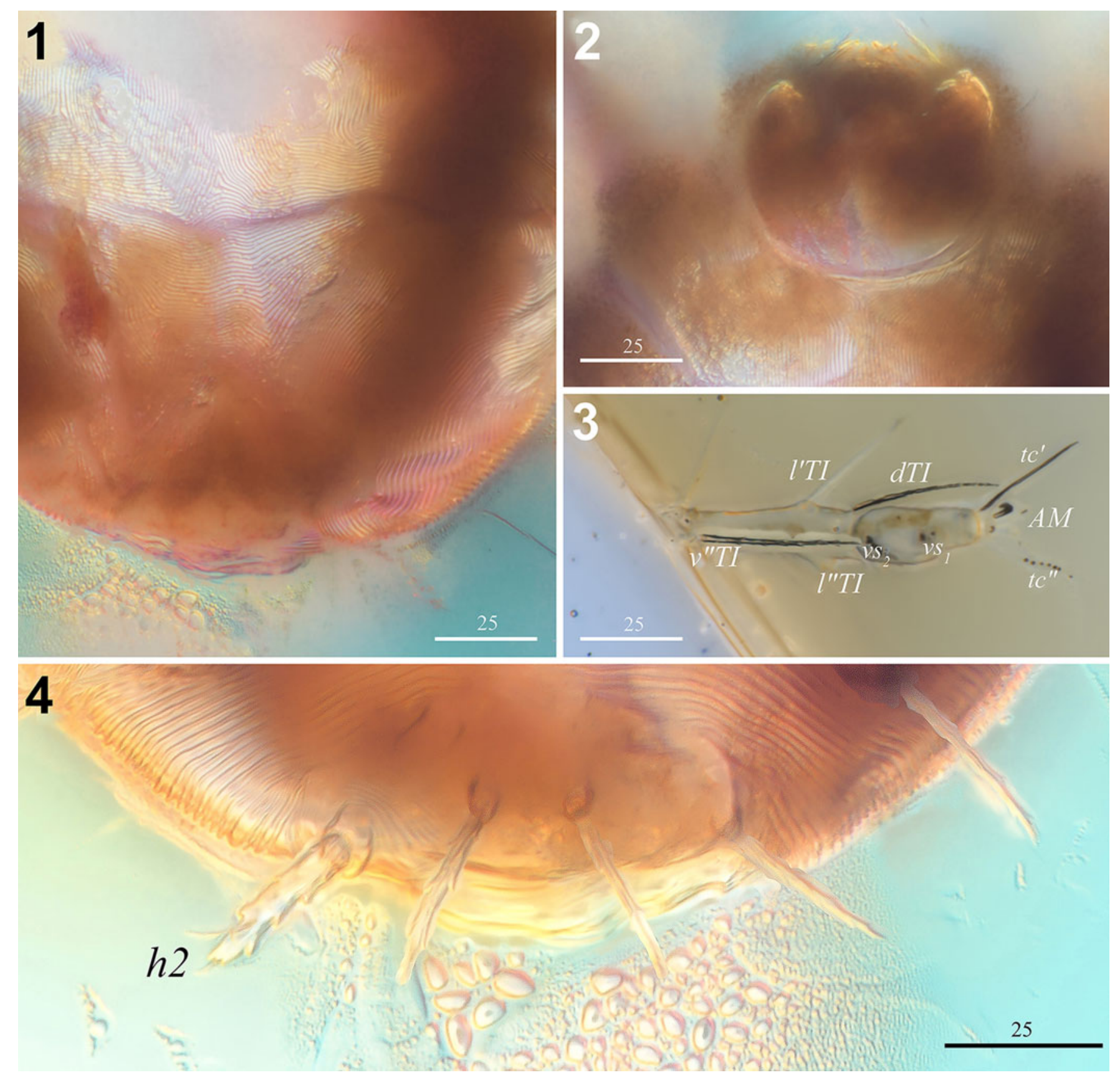

Figure 12. Neophyllobius glaesus n. sp. (GPIH 4995): (1) opisthosoma in ventral view (GPIH 4995a); (2) gnathosoma in ventral view (GPIH $4995 \mathrm{a})$; (3) left tarsus of leg II (GPIH 4995b); (4) opisthosoma in dorsal view (GPIH 4995a). $A M=$ ambulacrum (claws + tenant-hair empodium); $d T I=$ dorsal seta of tibia; $h 2=$ hypertrophied seta; $l T I=$ lateral seta of tibia; $t c=$ tectal seta; $v s_{1}, v s_{2}=$ midventral tarsal setae; $v T I=$ ventral seta of tibia; ${ }^{\prime}=$ anterior; $"=$ posterior. Scale bars $=25 \mu \mathrm{m}$.

indicated (Koç and Akyol, 2007). The inclusion of N. glaesus n. sp. has a hypertrophied (i.e., enlarged, thickened) left seta $h 2$ (Fig. 12.4). The right one is similar to other idiosomal setae. There are no species of Neophyllobius with setae $h 2$ distinctly thicker than other idiosomal setae, and this kind of asymmetry has not been reported for Camerobiidae; hence, the observed deviation is more likely to be an anomaly rather than a vertition. It would be interesting to study the microanatomical structure of such an abnormality, whether enlargement and thickening are associated with more intense cuticle deposition, cell proliferation, or all of these factors and whether the abnormality is affected by any individual mutation or is an error in ontogenetic development. Note also that hypertrophic setae occur in both acariform (e.g., Fernandez et al., 2014) and parasitiform mites (e.g., Mašán and Fenda, 2014) and mostly have some functions in sexual behavior. Hypertrophic setae may have originated at first from rare, random deviations (enlarging, thickening), which having a genetic background, were subject to sexual selection.

The shape of the prodorsum and position of setae $\mathrm{h} 1, \mathrm{~h} 2 .-$ Specimens mounted on microscope slides, especially those 


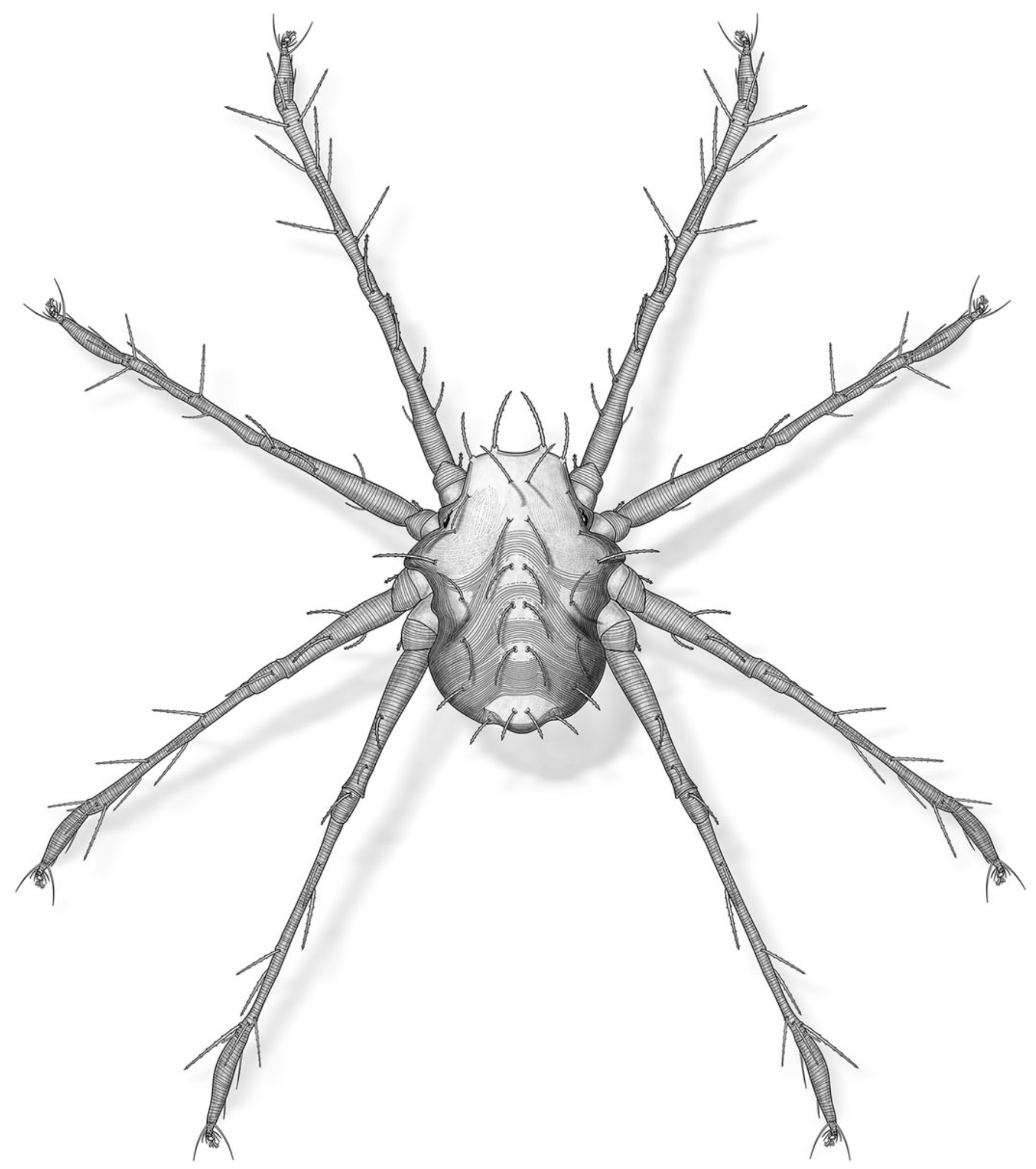

Figure 13. Neophyllobius glaesus n. sp., reconstruction of adult female stase.

without highly sclerotized cuticular structures, lose valuable information about the exact shape of their bodies. The flexible cuticle, which is additionally often softened before final preparation and flattened under two microscope slides (for the essential preparation techniques, see Evans, 1992; Walter and
Krantz, 2009), gives only an approximate shape of the body. In nature, it is subject to other forces and factors shaping the habitus, for example, through muscle attachments and its compositional structure (Alberti and Coons, 1999). A solid preparation made by the forces of nature, as inclusions in 
amber can be called, preserves the almost intact appearance of a once-living animal. Most of the studies on Camerobiidae were carried out on the basis of just such flattened individuals mounted on microscopic slides (some recent examples: Bolland, 2001; Akyol, 2013; Zeity and Gowda, 2013; Khanjani et al., 2014). This process generally causes the gnathosoma to be unnaturally situated slightly on the ventral part of the body but usually at the same level as the idiosoma. Scanning electron microscopic techniques were used for the first time by Bolland (1986) and then by Fan and Walter (2006) to image protonymphal Decaphyllobius gersoni Bolland, 1986 and adult Tycherobius stipula Walter and Fan, 2006 among Camerobiidae. Images from their papers clearly show that the prodorsum forms a well-distinguishable part of the anterior idiosoma in the shape of a trapezoid, partially protecting the gnathosoma from above. Khaustov and Abramov (2017) also used a scanning electron microscope, but the entire individual was not imaged. The studied inclusion of $N$. glaesus $\mathrm{n}$. $\mathrm{sp}$. has a similarly shaped prodorsum at the edges of which are placed vertical setae directed forward, and it almost entirely covers the gnathosoma. The specimen of $N$. electrus $n$. sp. has a round prodorsal idiosoma, but it distinctly forms a fold over the gnathosoma. Although no comprehensive studies have been conducted on the behavior of camerobiids, it can be hypothesized that the prodorsum may serve a protective function for the gnathosoma, and its shape may be taxonomically important. This feature dates back to at least the middle Eocene, from which Baltic amber probably originates (Weitschat and Wichard, 2002).

Bolland and Magowski (1990) indicated that the terminal situation of setae $h l$ in $N$. succineus is rather exceptional because, in extant species, these setae are situated rather on the dorsal side of the idiosoma. In N. electrus the same case can be found-setae $h l$ are placed marginally terminating the idiosoma. However, in $N$. glaesus, setae $h l$ are located clearly on the dorsal surface of the posterior idiosoma at some distance from the end of the body. So it seems that when interpreting this feature, the microscopic preparations of Recent specimens do not distort the true image of the setae situation. It is not excluded that the terminal location of the $h l$ setae may constitute a plesiomorphic character state in the genus Neophyllobius, or at least this state could have been more common in the Eocene species.

Brittleness of legs in Camerobiidae.-Bolland and Magowski (1990) stated that legs of camerobiids are difficult to manipulate and are prone to breaking off; hence, the complete specimen of $N$. succineus is a quite curious finding. The studied inclusions have an almost complete set of legs. In $N$. glaesus the tarsus of left leg I had been polished before the sample reached the author. In $N$. electrus, a tarsus and a half of the tibia of left leg I are lacking, and this loss most likely happened before the mite was trapped in leaking resin. Through these observations, the following questions arise. Since the legs of camerobiids are long and prone to breaking, is there a mechanism to regenerate lost parts by adding tissues after molting? Is there a mechanism for regeneration in adults, and if not, how does limb loss affect survival and thus the fitness of individuals? It seems that the ability of limb regeneration among Prostigmata is the weakest and with the highest mortality rate compared with other higher groups of mites (Rockett and Woodring, 1972) and takes place during molting. New, more-comprehensive studies of the regeneration capacity carried out on different representatives of prostigmatan mites may bring novel discoveries.

Lengths of genual setae d.-A curious feature among the representatives of the genus Neophyllobius that has never been discussed is a pattern of lengths of dorsal genual setae $d$. These setae may be short, with length equal to or slightly longer (two or three times) than that of the genu, or they may be very long, with lengths exceeding the combined length of the genu and the following tibia. Intermediate forms are probably present. However, we require more detailed studies and measurements of this character issuing precise criteria (e.g., setae reaching to half of the tibiae are common among species). N. bequartiodendri Bolland, 1991, N. texanus McGregor, 1950, and N. trisetosus De Leon, 1958 are examples of species with short setae $d$ on each genu I-IV. $N$. euonymi Bolland and Ripka, 2000, N. curtipilis, De Leon, 1958, and $N$. saxatilis Halbert, 1923 have setae $d$ short on genua I-III but distinctly long on genua IV. $N$. farrieri De Leon, 1958, N. fissus De Leon, 1967, and N. niloticus Bolland, 1991 all have setae $d$ on genua I-IV very long. $N$. armenica Bolland, 1991 and N. sycomorus Zaher and Gomaa, 1979 have the setae $d$ long on genua I, III, IV but short on genua II. In some other genera of CamerobiidaeBisetulobius, Camerobia, Decaphyllobius, and Tillandsobiusthese setae are always short, that is, the same length as the genu or slightly longer (Bolland, 1986). However, in Tycherobius, there may also be a different pattern of setae length, and Acamerobia has some setae $d$ distinctly longer (Fan and Walter 2006, 2011). Both N. electrus n. sp. and $N$. glaesus n. sp. have short dorsal setae of each genu I-IV. It is noticeable that the same pattern is present in N. succineus; hence, this feature is common for all known fossil Camerobiidae. It may be a plesiomorphic state of that characteristic, but a sample error is also likely, so the next findings may or may not falsify this hypothesis. If these setae have begun to lengthen in the Cenozoic era, determining the primary cause and function of the final product could be an interesting task. Dorsal setae $d$ are simple setae, not morphologically distinct from other leg setae, so a more probable function of them is sensory or/and protective rather than chemosensory. Minute setae $\kappa$ of genua I-II, which are probably present in all species but indiscernible in fossils, may be chemostimuli-responsive.

Neophyllobius, the most numerous and the oldest genus.Mites of the genus Neophyllobius have been found on all continents except Antarctica (Bolland, 1991). Their worldwide distribution can be due to their exceptional dispersal abilities or their long evolutionary history (camerobiids are slow-moving mites, and no dispersal forms or behaviors have been observed). The three known inclusions of Camerobiidae are evidence that the characteristics of the genus Neophyllobius were well developed in the Eocene, and the degree of morphological difference between the fossil species 
is comparable to that of species living today. Organic inclusions in Baltic amber come from ecosystems of Eocene Fennoscandia (northern Europe of that time). The presence of extant Camerobiidae in northern-central Europe- $N$. bialagorensis Bolland, 1991 (northern Poland), N. aesculi Bolland, 1983, N. vandebundi Bolland, 1991 (the Netherlands), N. plumifer Bolland, 1991 (central Poland), N. saxatilis Halbert, 1923 (Ireland) - may indicate that Neophyllobius returned to central and northern Europe after the last Pleistocene glacial period, which ended ca. 12,000 years ago (Weitschat and Wichard, 2002; Lomolino et al., 2010).

\section{Acknowledgments}

I thank A. Christian and K. Franke (Senckenberg Museum of Natural History Görlitz) for making the amber sample available for this study. I am grateful to J. Dunlop (Museum für Naturkunde, Berlin) and an anonymous reviewer for their suggestions, which improved the quality of the original manuscript. Scientific work was financed from the budget for science in the years 2018-2021, as a research project under the 'Diamond Grant' program (no. DI2017 002547).

\section{References}

Akyol, M., 2013, Two new species of the genus Neophyllobius Berlese (Acari: Camerobiidae) from Turkey: International Journal of Acarology, v. 39, p. 542-546.

Alberti, G., and Coons, L.B., 1999, Acari: mites, in Harrison, F.W., and Foelix, R.F., eds., Chelicerate Arthropoda: Microscopic Anatomy of Invertebrates, v. 8C: New York, Wiley-Liss, p. 515-1213.

Berlese, A., 1886, Acari dannosi alle piante cultivate: Padova, Sacchetto, p. 1-31.

Bingül, M., Doğan, S., and Doğan, S., 2017, Morphological abnormalities in some stigmaeid species of Eustigmaeus, Stigmaeus and Storchia (Acari: Raphignathoidea: Stigmaeidae): Systematic and Applied Acarology, v. 22, p. 2119-2126.

Bolland, H.R., 1983, A description of Neophyllobius aesculi n. sp. and its developmental stages (Acari: Camerobiidae): Entomologische Berichten, v. 43, p. $42-47$.

Bolland, H.R., 1986, Review of the systematics of the family Camerobiidae (Acari, Raphignathoidea). I. The genera Camerobia, Decaphyllobius, Tillandsobius, and Tycherobius: Tijdschrift Voor Entomologie, v. 129, p. 191-215.

Bolland, H.R., 1991, Review of the systematics of the family Camerobiidae, II. The genus Neophyllobius Berlese, 1886 (Acari: Raphignathoidea): Genus, v. 2 , p. $59-226$.

Bolland, H.R., 2001, Observations and description of Neophyllobius piniphilus n. sp. (Acari: Camerobiidae) from pine trees in the Netherlands: International Journal of Acarology, v. 27, p. 129-134.

Bolland, H.R., and Magowski, W.L., 1990, Neophyllobius succineus n. sp. from Baltic amber (Acari: Raphignathoidea: Camerobiidae): Entomologische Berichten, v. 50, p. 17-21.

Bolland, H.R., and Ripka, G., 2000, A new species of the genus Neophyllobius (Acari: Camerobiidae) from Hungary: International Journal of Acarology, v. 26, p. $357-361$.

Cuvier, G., 1812, Sur un nouveau rapprochement à établir entre les classes qui composent le Règne animal: Annales du Muséum National d'Histoire Naturelle, v. 19, p. $73-84$.

De Leon, D., 1958, The genus Neophyllobius in Mexico (Acarina: Neophyllobidae): Florida Entomologist, v. 41, p. 173-181.

De Leon, D., 1967, Some Mites of the Caribbean Area. Part I. Acarina on Plants in Trinidad; West Indies (Camerobiidae, Tenuipalpidae, Cheyletidae): Lawrence, Kansas, Allen Press, 66 p.

du Toit, B.J, Theron, P.D., and Ueckermann, E.A., 1998, A new genus and four new species of the family Camerobiidae (Acari: Raphignathoidea) from South Africa: International Journal of Acarology, v. 24, p. 3-19.

Dunlop, J.A., Penney, D., and Jekel, D., 2019, A summary list of fossil spiders and their relatives: World Spider Catalog v. 20.0 Natural History Museum Bern http://wsc.nmbe.ch [Nov 2019].
Evans, G.O., 1992, Principles of Acarology: Wallingford, CAB International, $563 \mathrm{p}$.

Fan, Q.-H., and Walter, D.E., 2006, A review of the genus Tycherobius (Acari: Camerobiidae), with descriptions of four new species from Australia: Zootaxa, v. 1121, p. 1-52.

Fan, Q.-H., and Walter, D.E., 2011, Acamerobia inflatus gen. n. \& sp. n. from Australia (Acari: Prostigmata: Raphignathoidea: Camerobiidae) with notes on the idiosomal chaetotaxy: Zootaxa, v. 3045, p. 45-56.

Fernandez, N., Coineau, Y., Theron, P., and Louwrens, T., 2014, Nannodromus reveilleti (Acari, Anystida, Saxidromidae) a new genus and species from South Africa: Zookeys, v. 378, p. 17-39.

Gerson, U., Smiley, R.L., and Ochoa, R., 2003, Mites (Acari) for pest control: London, Wiley-Blackwell, 539 p.

Grandjean, F., 1971, Caractères anormaux et vertitionnels rencontrés dans des clones de Platynothrus peltifer (Koch). Prèmiere partie: Acarologia, v. 13, p. 209-237.

Grandjean, F., 1972, Caractères anormaux et vertitionnels rencontrés dans des clones de Platynothrus peltifer (Koch). Chapitres I à VI de la deuxième partie: Acarologia, v. 14, p. 454-478.

Grandjean, F., 1973, Caractères anormaux et vertitionnels rencontrés dans des clones de Platynothrus peltifer (Koch). Chapitres VII à XIII de la deuxième partie: Acarologia, v. 15, p. 759-780.

Halbert, J.N., 1923, Notes on Acari, with description of new species: Zoological Journal of Linnean Society, v. 35, p. 363-395.

Kethley, J.B., 1982, Acariformes in Parker, S.P., ed., Synopsis and Classification of Living Organisms: New York, McGraw-Hill, p. 142-145.

Kethley, J.B., 1990, Acarina: Prostigmata (Actinedida), in Dindal, D.L., ed., Soil Biology Guide: New York, Wiley, p. 667-756.

Khanjani, M., Hoseini, M.A., Yazdanpanah, S., and Masoudian, F., 2014, Neophyllobius lorestanicus sp. nov. and N. ostovani sp. nov. (Acari: Camerobiidae) from Iran: Zootaxa, v. 3764, p. 441-454.

Khaustov, A.A., and Abramov V.V., 2017, A new species and a new record of raphignathoid mites (Acari: Raphignathoidea: Camerobiidae, Stigmaeidae) occurring in the galleries of bark beetles (Coleoptera: Curculionidae: Scolytinae) from Russia: Systematic and Applied Acarology, v. 22, p. 1385-1398.

Koç, K., and Akyol, M., 2007, Morphometric \& intraspecific variations between specimens of Tycherobius stramenticola and Tycherobius polonicus (Acari: Camerobiidae) from Turkey: Acarologia, v. 47, p. 139-142.

Koch, C.L., and Berendt, G.C, 1854, Die im Bernstein befindlichen Crustaceen, Myriopoden, Arachniden und Apteren der Vorwelt, in Berendt, G.C., ed. Die in Bernstein befindlichen organischen Reste der Vorwelt, gesammelt, in Verbindung mit Mehreren bearbeitetet und herausgegeben, v. 1: Berlin, Commission der Nicolaischen Buchhandlung, p. 103-111; 124.

Kramer, P., 1877, Grundzüge zur Systematik der Milben: Archiv für Naturgeschichte, v. 43, p. 215-247.

Kuznetsov, N.N., Khaustov, A.A., and Perkovsky, E.E., 2010, First record of mites of the family Stigmaeidae (Acari, Raphignathoidea) from Rovno amber with description of a new species of the genus Mediolata: Vestnik zoologii, v. 44, p. 545-547.

Lomolino, M.V., Riddle, B.R., Brown, J.H., 2010, Biogeography (fourth edition): Sunderland, Massachusetts, Sinauer Associates, 878 p.

Mašán, P., and Fend̆a, P., 2014, A new edaphic mite of the genus Pachyseius (Acari, Mesostigmata, Pachylaelapidae) from Făgăraş Mountains (Romania), with a key to world species: Systematic and Applied Acarology, v. 19, p. 137-143.

McGregor, E.A., 1950, Mites of the genus Neophyllobius: Bulletin of the Southern California Academy of Sciences, v. 49, p. 55-70.

Oudemans, A.C., 1909, Über die bis jetzt genauer bekannten Thrombidiumlarven und über eine neue Klassifikation der Prostigmata: Tijdschrift voor Entomologie, v. 52, p. 19-61.

Paredes-León, R., Corona-López, A.M., Flores-Palacios, A., and ToledoHernández, V.H., 2016, Camerobiid mites (Acariformes: Raphignathina: Camerobiidae) inhabiting epiphytic bromeliads and soil litter of tropical dry forest with analysis of setal homology in the genus Neophyllobius: European Journal of Taxonomy, v. 202, p. 1-25.

Reuter, E., 1909, Zur Morphologie und Ontogenie der Acariden mit besonderer Berücksichtigung von Pediculopsis graminum: Acta Societatis Scientiarum Fennicae, v. 36, p. 1-288.

Rockett, C.L., and Woodring, J.P., 1972, Comparative studies of acarine limb regeneration, apolysis, and ecdysis: Journal of Insect Physiology, v. 18, p. 2319-2336.

Seyfullah, L.J., Beimforde, C., Corso, J.D., Perrichot, V., Rikkinen, J., and Schmidt, A.R., 2018, Production and preservation of resins-past and present: Biological Reviews, v. 93, p. 1684-1714.

Sidorchuk, E., 2013, New technique for preparation of small-sized amber samples with application to mites, in Azar, D., Engel, M.S., Jarzembowski, E., Krogmann, L., Nel, A., and Santiago-Blay, J.A., eds., Insect Evolution in an Amberiferous and Stone Alphabet. Proceedings of the 6th International Congress on Fossil Insects, Arthropods and Amber: Leiden, Brill, p. 189201. 
Sidorchuk, E.A., 2018, Mites as fossils: forever small?: International Journal of Acarology, v. 44, p. 349-359.

Sidorchuk, E.A., and Vorontsov, D.D., 2016, Microscopic preparation of amber. http://www.amber.openscience.ru/index.php?page=overview\&lang=en [Nov 2019].

Sidorchuk, E.A., and Vorontsov, D.D., 2018, Preparation of small-sized 3D amber samples: state of the technique: Palaeoentomology, v. 1, p. 80-90.

Southcott, R.V., 1957, Description of a new Australian raphignathoid mite, with remarks on the classification of the Trombidiformes (Acarina): Proceedings of the Linnean Society of New South Wales, v. 81, p. 306-312.

Southcott, R.V., 1997, Dysmelia and other developmental abnormalities in prostigmatid mites (Acari): International Journal of Acarology, v. 23, p. 93-102.

Travé, J., and Vachon, M., 1975, François Grandjean 1882-1975 (Notice biographique et bibliographique): Acarologia, v. 17, p. 1-19.

van der Hammen, L., 1980, Glossary of Acarological Terminology, Volume 1. General Terminology: The Hague, Dr. W. Junk, B.V., 244 p.

Walter, D.E., and Krantz, G.W., 2009, Collecting, rearing, and preparing specimens, in Krantz, G.W., and Walter, D.E., eds, A Manual of Acarology [third edition]: Lubbock, Texas, Texas Tech University Press, p. 83-96.

Walter, D.E., Lindquist, E.E., Smith, I.M., Cook, D.R., and Krantz, G.W., 2009, Order Trombidiformes, in Krantz, G.W., and Walter, D.E., eds., A Manual of Acarology [third edition]: Lubbock, Texas, Texas Tech University Press, p. 233-420.
Weigmann, G., 2010, Anomalies of notogastral structures in poronotic oribatid mites (Oribatida: Poronota) interpreted as cryptic ancestral characters modulated by regulatory genes, in Sabelis, M.W., and Bruin, J., eds, Trends in Acarology: Proceedings of the 12th International Congress: Dordrecht, Springer, p. 17-22.

Weitschat, W., and Wichard, W., 2002, Atlas of Plants and Animals in Baltic Amber: München, Verlag Dr. Friedrich Pfeil, 256 p.

Zaher, M.A., and Gomaa, E.A., 1979, Genus Neophyllobius in Egypt with description of three new species (Prostigmata-Neophyllobidae): International Journal of Acarology, v. 5, p. 123-130.

Zakhvatkin, A.A., 1952, Division of the Acarina into orders and their position in the system of the Chelicerata: Parazitologischeskii Sbornik, v. 14, p. 5-46. [in Russian]

Zeity, M., and Gowda, C.C., 2013, A new species of Neophyllobius Berlese (Acari: Camerobiidae) from India: International Journal of Acarology, v. 39 , p. $547-550$

Zmudzinski, M., 2020a, Neophyllobius electrus I Baltic amber. figshare. Collection. https://doi.org/10.6084/m9.figshare.c.4757810.

Zmudzinski, M., 2020b, Neophyllobius glaesus I Baltic amber. figshare. Collection. https://doi.org/10.6084/m9.figshare.c.4758479.

Accepted: 8 March 2020 